\title{
Off the Deep End: Tonga's Continental Shelf Politics
}

\section{Abstract}

Tonga had gone off the deep end. It proposed to grow its ocean territory in length by 60 nautical miles southeast and southwest. Hardly anyone knew the particulars, apart from a select group of senior bureaucrats in the Government of Tonga persevering to make it happen. The Tongan public paid closer attention to who might come into government at the November 2014 election and whether any women would get voted into parliament.

Local media had spoon fed this slant to the masses which uncritically they consumed as the top news feed. Alternatively, raising awareness about continental shelf politics failed to appear on the public information menu. Why should it matter to ordinary Joe Blog Tongan scratching out a living in a distressed economy?

The story unfolds that Lord Ma'afu, the Minister for Lands, Environment, Climate Change, and Natural Resources entered office after the first partial submission on the outer limits of Tonga's continental shelf had been prepared. His predecessor Lord Tuita tabled the document for consideration at the United Nations in April of 2010.

Ma'afu was tasked with overseeing a second partial submission to acquire 60 nautical miles in the Lau-Colville Ridge, which he delivered to the United Nations headquarters 
in New York on April 23rd 2014. It would be weighed up the following year in 2015 (United Nations, 2014).

This essay prods two pressure points. Firstly, how did securing Tonga's continental shelf further than the 200 mile exclusive economic zone relate to deep sea mining? And secondly, what prompted Fiji's 2005 objection to the International Seabed Authority about Tonga's sovereign declaration over the Minerva Reefs? In the current geopolitical climate, how would the Tongan state navigate the ocean currents?

\section{What's in a shelf?}

Mr Tuita pointed out that the submission was a partial submission in respect of the eastern part of the Kermadec Ridge and that it was without prejudice to a second submission in respect of any potential continental shelf spaces extended beyond 200 nautical miles in the western part of the Lau Ridge, which would be made at a later stage. (Commission on the Limits of the Continental Shelf, 2010, pp. 12-13).

On May the 11th 2009 the Secretary-General of the United Nations acknowledged "receipt of the submission made by Tonga to the Commission on the limits of the continental shelf" (United Nations, 2009). Tonga barely made the deadline for submissions, scraping in by two days (Schofield, 2010, p. 164). Almost a year later at the twenty-fifth session of the Commission on the Limits of the Continental Shelf (CLCS) held at the United Nations headquarters from March 15th to April 23rd 2010, Lord Tuita presented Tonga's partial submission for consideration. He was accompanied by the solicitor general 'Aminiasi Kefu, government's principal geologist Kelepi 
Mafi, Tonga's permanent representative to the United Nations Sonatane Taumoepeau-Tupou, "and a number of advisors" (Commission on the Limits of the Continental Shelf, 2010, p. 12). For a poor country, the Tongan state spared no expense on travelling in a crowd from Nuku'alofa to New York.

It could be read in Tuita's speech that Tonga had faced similar challenges to that of other Pacific Island states. "Struggling to meet the 13 May 2009 deadline" with a halfdone paper that was not the complete picture of ocean sites Tonga wanted to go after, the Tongan minister politely nodded to the Commission on the Limits of the Continental Shelf (CLCS) who had a "huge workload and backlog of submissions to examine" (Schofield, 2010, p. 164; Commission on the Limits of the Continental Shelf, 2010, pp. 12-13). The question was how might a "huge workload and backlog" affect the quality of the process in fairly assessing a mountain of submissions, partial submissions, and "sets of preliminary information" by a scheduled time frame? (Schofield, 2010, p. 164). For Pacific Island states such as Tonga, how did the scarcity of technical expertise and financial backing impact on a developing country's capacity to prepare a submission under time constraints? 


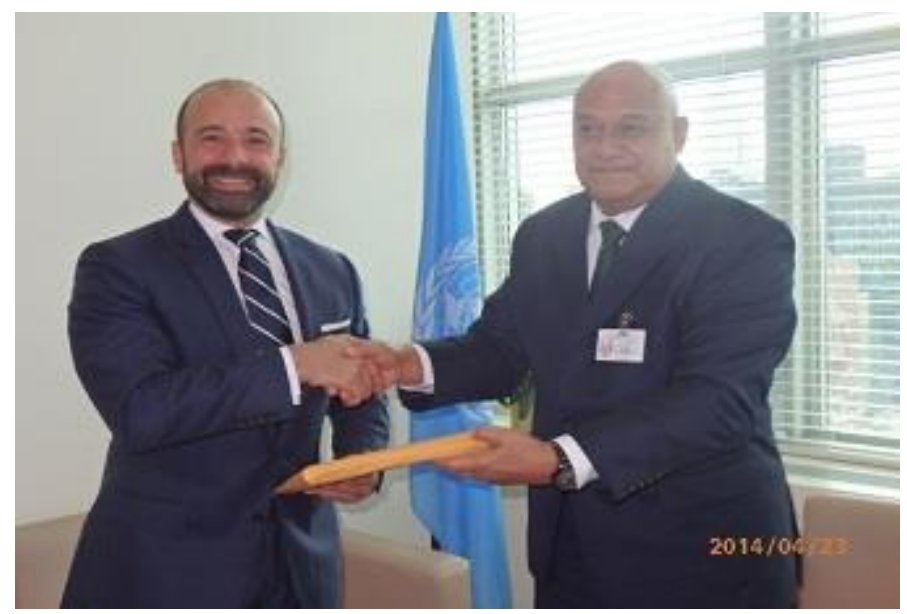

Lord Ma'afu (right) hands Tonga's second partial submission on the outer limits of the continental shelf to Miguel de Serpa Soares (left), the United Nations UnderSecretary-General for legal affairs and United Nations legal counsel at the New York headquarters. Photograph: Government of Tonga, 23 April 2014.

During that year from May 2009 to April 2010, Tonga focused on the minister's United Nations presentation on obtaining a south-eastern continental shelf outside of the country's 200 nautical mile exclusive economic zone (EEZ) in the Kermadec Ridge. The ocean zone they were after overlapped with New Zealand's continental shelf. But Tuita wanted his country's "partial submission" taken into account because New Zealand "had raised no objection to the Commission considering and making recommendations" on Tonga's claim.

Noting that "a second submission" was coming at a later date which the minister did not specify, Tonga also intended to go for continental shelf space past its south-western EEZ in 
the Lau-Colville Ridge (Commission on the Limits of the Continental Shelf, 2010, pp. 12-13). As maritime territory Fiji had set its sights on for their continental shelf, would the LauColville Ridge exacerbate discord with the Fijian government who prior to this, had opposed Tonga's proclamation over the Minerva Reefs?

In December of 2010 Lord Ma'afu got the job of Tonga's Minister for Lands, Environment, Climate Change, and Natural Resources in the Tu'ivakano government (Brown Pulu, 2012, 2013b). With the territory came responsibility for managing a second partial submission added to the one Lord Tuita put in. Tonga's outer continental shelf contention in the Lau-Colville Ridge complemented its first one in the Kermadec Ridge.

At the New York headquarters on April 23rd 2014 Ma'afu delivered in person the second partial submission, which took five years to compile, to Miguel de Serpa Soares, the United Nations under-general-secretary for legal affairs and United Nations legal counsel. The Tongan state now awaited their proposal's deliberation at the thirty-seventh session of the Commission on the Limits of the Continental Shelf, where the date would be set for New York in either January or February of 2015 (United Nations, 2014; Government of Tonga, 2014).

On 23 April 2014, the Kingdom of Tonga submitted to the Commission on the Limits of the Continental Shelf, in accordance with Article 76, paragraph 8, of the United Nations Convention on the Law of the Sea, information on the limits of the continental shelf beyond 200 nautical miles from the baselines from which the breadth of the territorial sea is measured in the western part of the Lau-Colville Ridge. (Commission on the Limits of the Continental Shelf, 2014). 
Theoretically, the minister who followed Ma'afu after the November 2014 election would see the second partial submission to its 2015 reading at the United Nations. Tonga's continental shelf claims looked to stretch across triplicate ministers from three separate governments dissimilar in their tactics on foreign diplomacy. Different to the former Sevele administration, under the present Tu'ivakano government Tongan diplomacy and international relations had spiralled downward with New Zealand and Australia expressly. To these traditional Western aid donors, the Tongan prime minister's single-mindedness on China and Asia relations coupled with his interpersonal communication as the head of foreign affairs came across offhand, brusque, and unsophisticated.

Plausibly the New Zealand and Australian governments cultivated and conveyed a certain political scepticism about Tonga's bilateral relations with China which could be said, had more to do with clutching on to their trade and aid donor primacy over South Pacific states. The fact was these Western states and Pacific Rim neighbours were home to sizeable Tongan populations. Overseas Tongans were large-scale remitters of wealth to the homeland state and felt baffled and betrayed that Tonga had forfeited traditional relationships with New Zealand and Australia in favour of attending to China as their main affair (Hill, 2014).

In terms of continental shelf politics, Tonga had to comply as scrupulously as a government could with the procedure for satisfying the legal obligations set out in article 76 of the United Nations Convention on the Law of the Sea (United Nations, 1982; Persand, 2005). Confined to an extensive process of partial submissions, overlapping borders, and country-to-country intercessions on delimiting boundaries, the last remaining Kingdom in the South Pacific was dead serious about getting hold of sea zones beyond its EEZ's south-eastern 
and south-western maritime borders (Prescott and Boyes, 2000).

In non-legalistic language why was getting Tonga's continental shelf recognised under international law vital to national security and geopolitical interests? Or was this more an official state line of indoctrination? By this, the raw motive behind extending the country's ocean domain was the allure of finding deep sea minerals to accelerate economic growth. Compounding this was that the United Nations formula which countries used to configure continental shelf submissions did not necessarily iron out the complexity that maritime claims by Pacific Island states overlapped. Therefore, delimiting boundaries got tangled in ongoing debates about where one territory stopped and another started.

Clive Schofield, director of research at the Australian national centre for ocean resources and national security at the University of Wollongong made it clear that the "majority of the potential maritime boundaries that exist in the Pacific Islands region have yet to be delimited" (Schofield, 2010, p. 157). He referred expressly to the situation of Pacific Island states where a rush to make United Nations submissions on the continental shelf before the May 13th 2009 cut-off date had meant that firstly, there was a plethora of "outer" or "extended" ocean borders on the waiting list for rubber stamp approval.

Secondly, many intersected into each other creating overlapping "maritime boundaries" and new perimeters redrawing the Pacific Ocean map. And thirdly, these "potential maritime boundaries" had not been delimited by the United Nations Commission on the Limits of the Continental Shelf (CLCS) according to the Convention on the Law of the Sea (1982). 
The situation has in recent times been exacerbated as a consequence of States from the region making submissions regarding the outer limits of their continental shelf rights extending beyond $200 \mathrm{~nm}$ [nautical miles] from their coasts. As a number of the areas of the 'outer' or 'extended' continental shelf subject to these submissions overlap with one another, additional potential maritime boundaries have come into existence that have also yet to be delimited. (Schofield, 2010, p. 157).

How exactly was the United Nations blueprint for setting definite limits, dimensions, and boundaries on new ocean territories of Pacific Island states going to work in light that these very borders were overlain and contested between countries? In short, who knows?

The second decade of the 21st century saw Pacific Islander academics echo and evoke 'Epeli Hau'ofa's romantic notion that the Pacific region's small island developing states cohabited a borderless ocean that knew no bounds (Hau'ofa, 2008). This was not true. The open ocean known as international waters could be legislated like land under a United Nations convention with explicit delimitations measuring sea areas claimed individually by countries who were not about sea sharing. On the contrary, the Pacific Islands were big ocean states that were about getting their piece of the deep sea pie.

Subsequently, an over idealised sentiment that Pacific governments had bonded together on climate adaptation to adverse weather and living conditions as their collective development priority was ambiguous. If that truly was the case, then why had delimiting ocean domains belonging to independent sovereign states become the most important and 
understated political and economic activity of the current times? (Schofield, 2010).

Adding 60 nautical miles to Tonga's 200 mile exclusive economic zone was laced to strengthening international rights as a sponsoring state of deep sea companies to explore the high seas and seek out mineral wealth (Brown Pulu, 2013a). In saying this, a head-on collision between climate adaptation that promoted environmental conservation and continental shelf politics in pursuit of territorial expansion for natural resources was not escapable but rather, fated.

\section{It is all about deep sea minerals}

Cleo Paskal and Michael Lodge co-authored a briefing paper for Chatham House, a London based institute on international affairs called A Fair Deal on International Wealth (Paskal and Lodge, 2009). The timeliness of the Paskal and Lodge's publication in February of 2009 was purposeful. It came out three months before member states to the United Nations who "ratified the Convention [on the Law of the Sea] before 13 May 1999 [had] until 13 May 2009 to" put in their continental shelf submissions (Paskal and Lodge, 2009, p. 2).

Succinctly the co-authors encapsulated the "sudden interest in the OCS [outer continental shelf]" (Paskal and Lodge, 2009, p. 2). For the majority of claimants who were poor countries, interest was driven by potential geopolitical and economic security; the latter - economic - cultivating expectations that extending state borders beyond the 200 nautical mile EEZ would lead to "underwater resources," namely minerals (Paskal and Lodge, 2009, p. 2).

The is a sudden interest in the OCS [outer continental shelf] as States that ratified the Convention [on the Law of the Sea] before 13 May 1999 have only 
until 13 May 2009 to submit that claim. For many developing nations, the added seabed could be economically critical. Land-poor countries such as Barbados, Tonga and Palau are hoping to secure their financial future with underwater resources. Only fifteen of the States that are estimated to have a potential OCS claim do not have developing-country status. (Paskal and Lodge, 2009, p. 2).

For Pacific Island states, however, there were two unknown political considerations which outer continental shelf submissions overlooked because the prospect of acquiring an enlarged territory of sea riches outweighed precautions to put the brakes on and tread carefully. Foremost, Paskal and Lodge noted there was climate change. If "sea-level rise" sunk low-lying atoll states below the water line, as was the predicament facing Kiribati, Tuvalu, and the Marshall Islands, then how could these small island developing states call themselves a state or even claim a continental shelf without a land-base? (Paskal and Lodge, 2009, p. 7).

In the most extreme case, an entire nation could be submerged by sea-level rise, which could potentially extinguish its entire claim (and even statehood), and would certainly affect Article 82 implementation in the affected areas. (Paskal and Lodge, 2009, p. 7).

Related to this was the bureaucratic red-tape of article 82 of the United Nations Convention on the Law of the Sea (1982) promising "a portion of the revenue from the extraction of nonliving resources on the OCS [outer continental shelf] must be disbursed 'on the basis of equitable sharing criteria, taking into account the interests and needs of developing States, 
particularly the least developed and the land-locked among them' (Paskal and Lodge, 2009, p. 1).

If article 76 of the United Nations convention was the gate Pacific Island states had to pass through for outer continental shelf authorisation, then article 82 was the next hurdle poor countries were forced to jump for an "equitable" share of the illusive gold at the bottom of the ocean (Paskal and Lodge, 2009, p. 1).

However, this article [82] is a complex provision. It is also the only provision in the Convention setting out an international royalty concerning an activity within national jurisdiction. It contains a rough and untested formula to determine payments or contributions. The uniqueness and complexity of Article 82 demand careful consideration of the obligation, principles criteria for distribution of benefits, procedural aspects, the role of the [International Seabed] Authority, the role of the OCS [outer continental shelf] States, and economic and temporal issues. (Paskal and Lodge, 2009, p. 3).

Paskal and Lodge observed that article 82 might have contained a certain "uniqueness" in laying down "an international royalty" regime on mineral "payments," but it was also riddled with "complexity," particularly when it came to defining the legal "obligation" of states in sponsoring seabed mining companies (Paskal and Lodge, 2009, p. 3).

On February 1st of 2011 the Seabed Disputes Chamber which was the International Tribunal for the Law of the Sea based in Hamburg, Germany, issued a detailed seventy-six page advisory opinion. The chamber was responding to a request made almost a year earlier by the Council of the International Seabed Authority on 11 May 2010. 
Two years prior at the council annual meeting on May 30th 2008, the seabed authority had "deferred action on the applications for approval of plans of work for exploration by Nauru Ocean Resources Inc. and Tonga Offshore Minerals Ltd., sponsored respectively, by the Governments of the Republic of Nauru and the Kingdom of Tonga" (International Seabed Authority, 2008a, p. 1). With direct reference to Nauru and Tonga, the council first sought legal clarification on what the "responsibilities and obligations" of states were when sponsoring seabed mining companies (Seabed Disputes Chamber, 2011, p. 6).

Signalling to Nauru and Tonga whose applications to the International Seabed Authority to sponsor subsidiaries of Nautilus Minerals Incorporated were pending council decision, the Seabed Disputes Chamber made a ruling on state liability under the United Nations Convention on the Law of the Sea (1982). (International Seabed Authority, 2008a, 2008b). In a nutshell the chamber stated that "responsibilities and liability of the sponsoring State apply equally to all sponsoring States, whether developing or developed" (Seabed Disputes Chamber, 2011, p. 48).

Concisely this meant there were no reduced provisions under international law for Tonga and Pacific Island states because they were developing countries. The Tongan state was under legal obligation to get a seabed minerals bill through the legislature quick smart and instated into national law.

As a sponsoring state it was liable for mining damage caused to the ocean floor on the same level of culpability as developed countries. If Tonga did not have sufficient legislation in which it could follow due diligence it risked liability and was in breach of the United Nations Convention on the Law of the Sea (1982). 
158. It may therefore be concluded that the general provisions concerning the responsibilities and liability of the sponsoring State apply equally to all sponsoring States, whether developing or developed. 159. Equality of treatment between developing and developed sponsoring States is consistent with the need to prevent commercial enterprises based in developed States from setting up companies in developing States, acquiring their nationality and obtaining their sponsorship in the hope of being subjected to less burdensome regulations and controls. The spread of sponsoring States "of convenience" would jeopardize uniform application of the highest standards of protection on of the marine environment, the safe development of activities in the Area and protection of the common heritage of mankind. (Seabed Disputes Chamber, 2011, p. 48).

Did Tonga have a national law on seabed mineral exploration and exploitation? In brief, no. Was it likely to get one soon? Again, the short retort was who knows? There was, however, one certainty: the Tongan public were by-and-large uninformed, misinformed, and formally cut out of the state information loop which threw up a query.

Adopted by the United Nations General Assembly at the 61st session on September 13th 2007 was the Declaration on the Rights of Indigenous People (United Nations, 2007a). A majority of 144 voting member states out of 192 adopted the resolution. Tonga was counted as one of the thirty-four nonvoting countries alongside most independent Pacific Island states, with the exception of Samoa who abstained from voting (United Nations, 2013b). The declaration was not a legally binding mechanism according to international law but it did, however, indicate what member states generally felt were 
global standards when it came to a country's responsibility towards protecting indigenous people's rights.

On this point Catherine Ashton, High Representative of the European Union for foreign affairs and security policy observed the "Declaration is a key tool for promoting human rights, but the challenge remains in putting it into practice" (Ashton, 2013). If the Tongan government did recognise Tongan citizens as indigenous people, which clearly it did not as an independent sovereign state that was not formally colonised by the British Empire, then adopting the 2007 United Nations Declaration on the Rights of Indigenous People would have given clear guidelines about how to "consult and cooperate in good faith" (United Nations, 2007a).

To illuminate, what governance procedures could Tongans use to hold the state to account on gaining citizen consent for "any project affecting their lands or territories and other resources, particularly in connection with development, utilization or exploration of mineral, water or other resources?" (United Nations, 2007a). The short answer; there were no governance procedures of which the state conscientiously informed their public of.

The terse question; if the Tongan state did not "consult and cooperate in good faith" with its citizens on national development projects, then how did such disregard for public information and benefit controvert international principles underpinning the application processes for acquiring a state's outer continental shelf as well as sponsorship of seabed mining? (United Nations, 2007a).

\section{Article 32}

2. States shall consult and cooperate in good faith with the indigenous peoples concerned through their own representative institutions in order to obtain their free and informed consent prior to the approval of any 
project affecting their lands or territories and other resources, particularly in connection with the development, utilization or exploration of mineral, water or other resources. 3. States shall provide effective mechanisms for just and fair redress for any activities, and appropriate measures shall be taken to mitigate adverse environmental, economic, social, cultural or spiritual impact. (United Nations, 2007a).

Tonga's Attorney General Neil Adsett spoke to Matangi Tonga, a local media outlet in mid-March of 2013. He predicted that five months down the line in August, his office at the Government of Tonga crown law department would have a deep sea mining bill into the legislative assembly for its first reading. The bill never arrived in the House.

To this day, more than a year has passed since Adsett's avowal that the "bill is on our legislative program for 2013" (Matangi Tonga, 2013a). The truth was Tongans were still anticipating when this mysterious bill, which had not been officially released for public review and submissions, would materialise.

The bill is on our legislative program for 2013 so we hope it will go to parliament in July or August. ... Sea mineral exploration companies need a license to prospect, explore or mine, and the environmental issues are very strictly guarded and they pay royalties to Tonga. (Tonga Attorney General Neil Adsett cited in Matangi Tonga, 2013a).

If the Tongan state's sponsorship of deep sea mining, the national legislation required to protect the state from liability, and all it encompassed was elusive to citizens, then it was the opposite for Paula Taumoepeau. He headed Tonga Offshore 
Minerals Limited, the country's one seabed minerals company at work outside the exclusive economic zone which monopolised this national industry.

Critical to figuring out the Tongan government's relationship to Tonga Offshore Minerals Limited as its state sponsor of seabed exploration is to realise that the state was in the business of privatising national natural resources (Sato, 2014). This government policy failed to ask for public opinion on denationalising deep sea minerals when calculating the costs and benefits to the country. Given the legal complexity and high-risk involved the argument that Tonga stood to lose more than gain was graspable.

Cited in Matangi Tonga, Taumoepeau commented on his company's participation at a regional workshop on deep sea minerals hosted in Tonga from 11 - 15 March 2013 which was co-organised by the Secretariat of the Pacific Community and the European Union (Brown Pulu, 2013a). "We hope the industry will continue to be consulted on deep sea minerals," he confided (Matangi Tonga, 2013b).

Obviously the Tongan government was committed to "consult and cooperate in good faith" with its sponsored deep sea minerals company on the proposed law governing the industry (United Nations, 2007a). But the question remained as to why Tongan citizens were not, for the most part, included in the information sharing and consultation procedure as a sounding board for gathering public views.

For Nautilus, we had the opportunity to put our views forward and updated about our project, as there were a lot of misconceptions about what we do. ... One workshop would not solve the issues at once, that's why it is important to have ongoing dialogues and we hope the industry will continue to be consulted on deep 
sea minerals. (Paula Taumoepeau cited in Matangi Tonga, 2013b).

\section{Tonga in a seabed of mining}

By layman's terms or in simple language, the high seas referred to international waters; that is, the open ocean which is distant from land and under no particular country's national jurisdiction and territorial control. January of 2012 saw Tonga become the second small island developing state next to Nauru to make a successful application to the International Seabed Authority. The Government of Tonga had obtained approval to be a sponsoring state of deep sea mining companies exploring with a mind to exploit, given there were sufficient mineral deposits in international waters.

An agreement reached between the seabed authority and the Tongan state gave a Canadian company Nautilus Minerals Incorporated exclusive rights to mine a " $74,153 \mathrm{~km} 2$ [seabed located] in the Clarion-Clipperton Zone of the Pacific Ocean," which was a "marine area beyond the limits of [Tonga's] national jurisdiction" (International Seabed Authority, 2012).

The treasure hunt was for polymetallic or manganese nodules that lay four to six thousand metres down on the seafloor. The rock fossils contained financially valuable properties of nickel, copper, and cobalt of which Tonga would receive royalties from the company's discoveries.

Nautilus Minerals Incorporated had formed a subsidiary called Tonga Offshore Mining Limited of which Paula Taumoepeau, a Tongan national was the country manager. As a prescription under Tongan law the parent company was required to register as a business in Tonga. The Tongan branch that was created, however, was still Nautilus Minerals Incorporated with a Friendly Islands ring to its name. 
The International Seabed Authority and Tonga Offshore Mining Limited (TOML) today signed a 15-year contract for exploration for polymetallic nodules in an area covering $74,153 \mathrm{~km} 2$ in the Clarion-Clipperton Zone of the Pacific Ocean. This marine area beyond the limits of national jurisdiction is one of a number of reserved areas earmarked for developing countries such as the Kingdom of Tonga and was ceded by ISA contractors from Germany, Japan, the Republic of Korea and France. (International Seabed Authority, 2012).

To obtain a contract for exploring and exploiting the seabed at high seas, the Tongan government had to appeal to sponsoring states who were current contractors of the International Seabed Authority. They needed their agreement to share mining space in international waters. A selection of "ISA contractors from Germany, Japan, the Republic of Korea and France" conceded to Tonga's entry into mineral exploration of a section of the Pacific Ocean called the ClarionClipperton Fracture Zone.

"Germany, Japan, the Republic of Korea and France" were already mining this area as state sponsors of commercial businesses (International Seabed Authority, 2012). All up, the International Seabed Authority stated it had twelve contracts in the Clarion-Clipperton Fracture Zone, the clear majority of nine going to developed countries with Nauru, Tonga, and Kiribati who were soon to sign a contract, making up the three developing states (International Seabed Authority, 2014).

The financial superiority of developed states allowed them to be state sponsors for companies from their own countries, of which for some governments they held shares in. In the Republic of Korea's case, the government ran its own company (International Seabed Authority, 2012). By comparison, China 
and Japan who had two sections of international waters they were mining in the Clarion-Clipperton Fracture Zone and the Western Pacific Ocean were guarantors for state-owned companies.

Parked on what appeared to be a quickly crowding up Clarion-Clipperton Fracture Zone was also an intergovernmental company, the Interoceanmetal Joint Organization. Shareholders here were a an association of sponsoring states from Bulgaria, Cuba, the Czech Republic, Poland, the Russian Federation, and Slovakia (International Seabed Authority, 2014). Conspicuously this seabed minerals alliance was made up of states constituting the former Union of Soviet Socialists Republics (USSR) along with Cuba, which continues to be a socialist republic.

Since the 1991 breakup of the Soviet Union into the Russian Federation and a host of independent sovereign states, the economies of the past Eastern European bloc have accelerated through gas, oil, and mineral exploitation of natural resources within their respective countries. It is noteworthy that the Interoceanmetal Joint Organization was set-up to explore deep sea minerals in the northern Pacific Ocean which historically lies outside the sphere of influence of these European states and Cuba, a Caribbean island state. More than that, the Clarion-Clipperton Fracture Zone is located in international waters that can be considered part of the security and economic interests of the United States of America.

My point is the diplomatic relations between the United States and the Russian Federation and Cuba are politically volatile. Even after the end of the 20th century Cold War, America's disparagement of the 2014 succession of the Ukrainian state of Crimea to the Russian Federation has highlighted United States and NATO (North Atlantic Treaty Organization) hostility towards Russia. Could the 
Interoceanmetal Joint Organization be interpreted as political provocation by America?

If so, how were small island developing states such as Nauru, Tonga, and Kiribati caught in the crossfire of an American superpower that assumed the northern Pacific Ocean was its strategic domain in respect of newcomers to Pacific regional politics and influence such as the Russian Federation? America and its Western allies Australia and New Zealand had China's economic primacy in the Pacific to contend with. Would Russia's presence in Pacific seabed mining tip the scales?

Yoichiro Sato, a political scientist at Ritsumeikan Asia Pacific University authored an opinion piece for the New Zealand International Review (Sato, 2014). Titled Tonga's risky seabed mining ventures, Sato's paper argued a double-edged critique as to why this small island developing state was unfavourably positioned legally and financially to manage high-risk operations as a sponsoring state of deep sea mining multinationals.

Sato first pointed to "the risks of losses and liabilities" in a developing country's business scheme regulated by international law, regulations, and competencies at operating by the same standards as developed countries. Who would pay "for the poorly developed governance competency of Tonga?" he asked. The Tongan "taxpayers" was his response (Sato, 2014, p. 19).

The Tongan government's involvement in seabed mining in international waters exposes it to the risk of losses and liabilities that will have to be shouldered by the taxpayers. For the poorly developed governance competency of Tonga, seabed mining simultaneously offers too much economic lure and demands too much supervisory responsibility. (Sato, 2014, p. 19). 
Sato then gestured to the "absence of transparent law governing the deep-sea mining" industry in Tonga. Not only did the Tongan government have an obligation under international law to protect the state from liability, which effectively would fall on the "taxpayers," but there was the matter of privatising the country's natural resources without legal precautions for ensuring "a fair return to the government coffer" (Sato, 2014, p. 19).

The absence of transparent law governing the deepsea mining and the Tongan government's decision to sign international joint exploration and production agreements have set the stage for the partial privatisation of national resources without a fair return to the government coffer. (Sato, 2014, p. 19). 
A Russian oil prospector of Kazakhstan and a Las Vegas entertainer

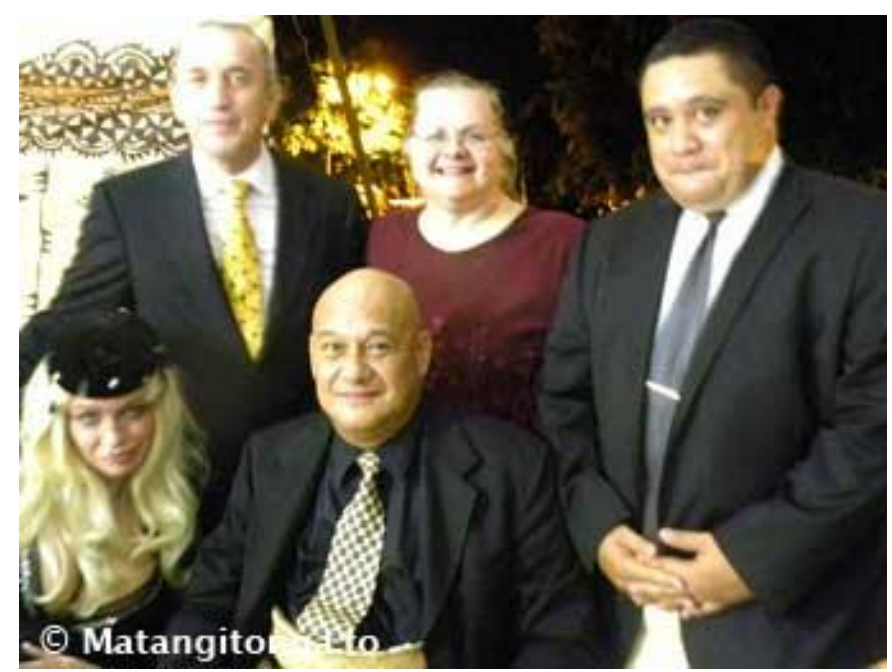

Standing left to right: Kairat Sydykov, Christine Utu'atu, 'Aminiasi Kefu. Sitting left to right: Natalia Lapina, Lord Ma'afu. Photograph: Matangi Tonga, 22 February 2012. The Matangi Tonga Online photograph and article is incorrectly dated. It should read 31 January 2011.

A large swathe of Tonga's seabed oil rights have been given to an enigmatic Russian [Kairat Sydykov] from companies that cannot be traced and to its multimillionaire crown princess [Pilolevu Tuita]. The deal echoing other Tongan embarrassments - a court jester who took off with millions and a Korean religious group who duped the government claiming natural gas could be extracted from Tongan seawater - was sealed with a party serenaded by a voluptuous Russian [entertainer, Natalia Lapina] from Las Vegas. (Field, 2011c). 


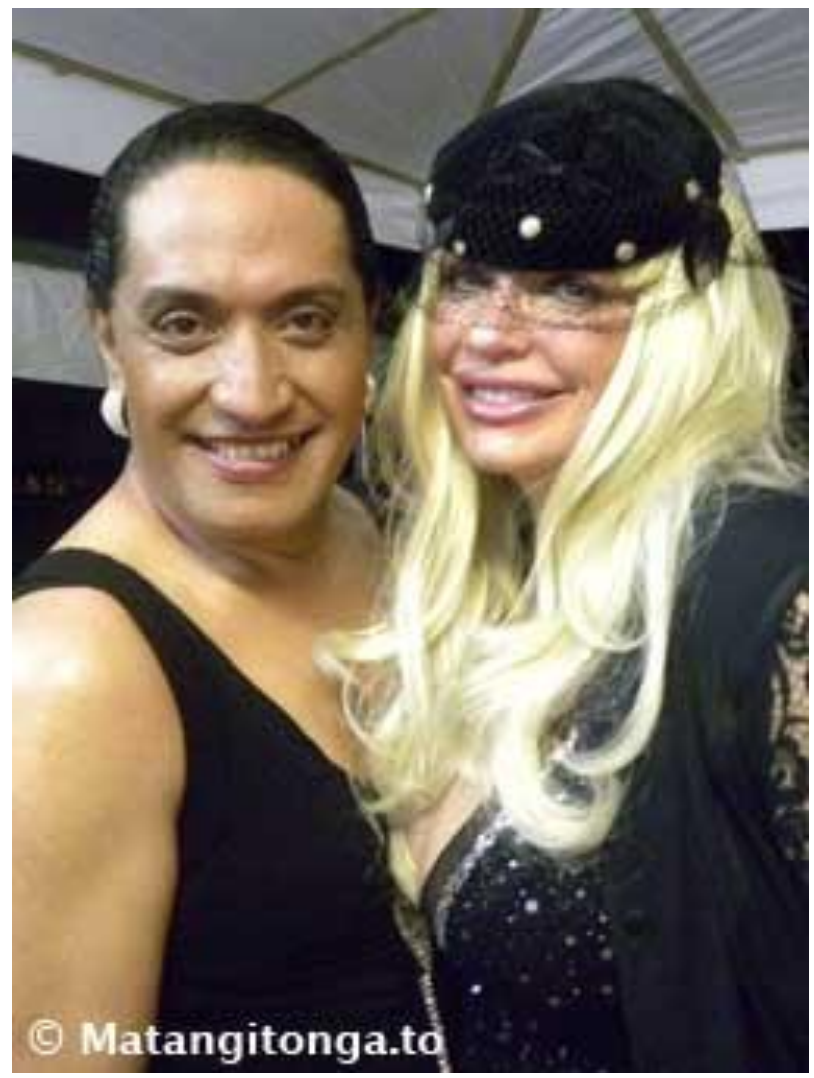

Left to right: Joey Mataele, Natalia Lapina. Photograph: Matangi Tonga, 22 February 2012. The Matangi Tonga Online photograph and article is incorrectly dated. It should read 31 January 2011.

Also there was Tonga's premier transsexual entertainer Joey Mataele and [Russian entertainer from Las Vegas] Natalia Lapina, complete with long flowing blond hair and a deep cleavage. (Field, 2011c). 
If deep sea minerals were tricky to find in international waters and for the Tongan state to exploit for corpus amounts of money, then petroleum mining within Tonga's exclusive economic zone proved slippery. Most definitely, something appeared to be amusingly and derisorily wrong with the picture that New Zealand journalist Michael Field painted with tongue-in-cheek lavishness. Perhaps it was the interplay of what readers visualised in the Matangi Tonga Online photographs featured in an article titled US group celebrates new oil exploration agreements with Tonga. The festivity took place at the Dateline Hotel in Nuku'alofa on Friday 28 January 2011 featuring in a Matangi Tonga Online write-up on Monday 31 January 2011, although it was incorrectly dated on the company's website as 22 February 2012.

Tonga's "who's who in the zoo" had gathered for a celebrity party. ${ }^{1}$ What exactly called for the carnival atmosphere was hazy. Drawn in was an odd mix of royalty, nobility, cabinet ministers, senior government bureaucrats, overseas diplomats, and elite business owners; many of whom were distant and detached from each other in their profit-making pursuits and political views.

A Russian petroleum prospector took centre stage of the high-profile occasion; Dr Kairat Sydykov, whose work history included the oil fields of Kazakhstan, a central Asia state with the "second largest oil production among the former Soviet republics after Russia” (U.S. Energy Information, 2013). Now, Sydykov was part of a transnational corporation located in Denver and London called the Modulus-Baringer Group; not that any person outside a Russian oil oligarch's inner-circle could confirm this was an accurate profile.

What was the common ground between the former Prime Minister Dr Feleti Sevele and the current Prime Minister Lord Tu'ivakano in respect to mining Tonga's ocean floor for which they had prioritised their attendance at this function? The 
hotel spectacle reflected to ordinary Tongan folks on the outer limits of the top shelf (not to be confused with the continental shelf) an assemblage of the nation's powerhouse; that is, a social outing for Tonga's asset wealthy who characterised the privileged few bordering the corrupt and unashamed to flaunt it in the faces of poor citizens who lived without, with little, and with want.

In local media, Matangi Tonga reported that the ModulusBaringer Group represented by Dr Kairat Sydykov was in town to celebrate successful contract negotiations with the Tongan government. The Friday night party saw Sydykov bring in a Las Vegas entertainer to sing at the Dateline Hotel called Natalia Lapina who was Russian by origin too. He "had spent four days in negotiations" with Tonga's Minister of Lands Lord Ma'afu and a team of senior government officials (Matangi Tonga, 2012).

Out of discussions emerged three petroleum exploration contracts for "three Tonga registered companies," subsidiaries of the Modulus-Baringer Group which government press releases by the Prime Minister's Office referred to as the Modulus Pacific Company Limited registered in Tonga (Matangi Tonga, 2012; Prime Minister's Office, 2013). Presently the Modulus-Baringer Group as a parent company had disappeared from cyber space, no longer appearing as a corporate website.

The exploration "agreements" between the Tongan state and Modulus-Baringer were transferred by the former Sevele administration in office from 2006 to 2010 over to the Tu'ivakano regime governing from 2010 to 2014 (Matangi Tonga, 2012). Uttered within government circles was that the current prime minister had been unyielding, despite concerns raised by senior cabinet ministers as to whether the previous arrangements would be unquestionably shouldered by his government, that he wanted the settlement signed off. Why 
was a review of prior deals not allowed in this case with the Tongan premier's push for signatures?

The Attorney General, 'Aminiasi Kefu, said that a negotiation team including Lord Ma'afu (now Minister of Lands), Busby Kautoke Chief Secretary to Cabinet, and Kelepi Mafi the government geologist, had spent four days in negotiations with the Modulus-Baringer Group, which resulted in three petroleum agreements with three Tonga registered companies. He said that the former Deputy Prime Minister Dr Tangi had signed the agreements last January on behalf of the Tonga government, under a 1985 law. (Matangi Tonga, 2012).

"There is corruption in government," stated Sione Taione in parliament on October 16th 2013 (Fonua, 2013). Taione, the people's representative for Tongatapu constituency number 8 did not mix his words, targeting the Prime Minister's Office by his judgement. Tonga's legislative assembly was in the middle of receiving the 2012 annual report of the Ministry of Lands, Environment, Climate Change and Natural Resources delivered by the Minister Lord Ma'afu when deliberations became wedged. Who was the Modulus-Baringer Group, the oil multinational said to be based in the United States and the United Kingdom and led by Dr Kairat Sydykov?

Long-standing reporter on Tonga's parliament Pesi Fonua disentangled the convoluted story in a Matangi Tonga commentary. In the House, Taione had raised objection with two points he interpreted from Lord Ma'afu's annual report for his ministry. Principally, the company Modulus-Baringer was thought to have been "administered and managed by the Prime Minister's Office," which if it was, presented an outright conflict of professional and public interest (Fonua, 2013). Why 
would the highest office in the public service be administering a private sector oil business?

Concomitantly, there was princess regent Pilolevu's link "with the company" which Taione figured had to entail nepotism at play. For one, Modulus-Baringer "did not pay any license fees." But significantly, why did this particular company have an "exclusive [petroleum mining right] to the whole [EEZ ocean] of Tonga?" (Fonua, 2013).

Most intriguing though, according to the report, Modulus is administered and managed by the Prime Minister's Office. Sione said that Princess Pilolevu was affiliated with the company and pointed out a disparity in seabed rights favouring the Modulus, a company that did not pay any license fees. According to Sione three mineral exploration companies were confined to one small area in their seabed exploration for minerals in comparison to Modulus, which has the exclusive right to the whole of Tonga. (Fonua, 2013).

Dr Sitiveni Halapua, the people's representative for Tongatapu constituency number three entered into the line of parliamentary cross-examination, offering suggestions on how to get some accountability around the Prime Minister and his office. The lack of fiscal and political accountability for the premier, his acting secretary, his advisors, and entire office staff put the opposition in continuous discomfort; a type of distress that kept sparking up without any parliamentarian being able to get to the bottom of it and correct the problem, fix a non-transparent system, once and for all.

Dr Sitiveni Halapua, the $P R$ [people's representative] No 3 for Tongatapu, pointed out that according to the report Modulus was administered and 
managed by the PM's [prime minister's] Office. He said it was a mystery as to why this was not stated in the PM's Annual Reports despite the fact that it was reported in the Annual Report of the Ministry of Land. He moved for the administration and management of the Modulus to be moved from the PM's office to the Ministry of Land. He also moved for the annual report of the Ministry of Land to be included in reports of mineral explorations that have been carried out, and a detailed report on all the companies that are exploring for mineral, gas and oil on Tonga's seabed. (Fonua, 2013).

The prime minister himself was overseas at the time. On returning to Tonga, a statement was issued from his office which made the premier's personal disgruntlement with Taione prying into the business of Modulus Pacific Company Limited loud and clear.

The Prime Minister's Office wishes to issue this statement in rebuttal of the unfounded and cheap allegation of corruption made by Sione Taione People Representative for Tongatapu No. 8 against the Prime Minister and his Office. (Prime Minister's Office, 2013).

Fired at Sione Taione's discussion was an opening volley arguing that the "management of this company," was not in any way, shape or form under the prime minister's administration (Prime Minister's Office, 2013).

[Modulus Pacific Company Limited] administers and manages its own affairs through its Directors and its Management Team. The Prime Minister's Office is not involved in any way with the management of this 
company. The allegation that Modulus Pacific is administered and managed by the Prime Minister's Office is totally false (Prime Minister's Office, 2013).

The governance of Modulus Pacific Company Limited was a different story. An advisory committee ran out of the Prime Minister's Office under the chairmanship of the "Chief Secretary and Secretary of Cabinet" had been authorised to guide the Minister for Lands Lord Ma'afu on matters concerning the company in relation to the Tonga Petroleum Mining Act (Revised Edition 1988). (Prime Minister's Office, 2013). Consisting of three senior bureaucrats on behalf of the Government of Tonga in collaboration with three company delegates from Modulus Pacific Company Limited, the committee looked as if to take on a ministerial advice-giving role merged into a quasi-governance body.

What Sione Taione did not understand and failed to find out is that the advisory Committee consisting of the Chief Secretary and Secretary to Cabinet, Deputy Secretary in charge of Geology Division of the Ministry of Lands, Environment, Climate Change and Natural Resources; the Solicitor General and three members appointed by Modulus Pacific and its two partner subsidiary companies is responsible for advising the Minister of Lands in his role as the competent authority. The Chairman of the Committee is the Chief Secretary and Secretary to Cabinet and the Committee operates from the Prime Minister's Office. The Minister of Lands, Environment, Climate Change and Natural Resources, is the sole competent authority for all exploration and mining of petroleum under the Petroleum Mining Act [Revised Edition 1988]. The Minister is supported by the Advisory Committee (Prime Minister's Office, 2013). 
Modulus Pacific Company Limited of Nuku'alofa, Tonga was registered on October 14th 2009, almost five years ago. The company directors were recorded since January 11 th 2013 as Lucy 'Ilaiu and Maria Elliot. As well, Her Royal Highness Princess Salote Mafile'o Pilolevu Tuita was named as owning 30 shares in contrast to the majority shareholder Tonga Petroleum Corp with 970 shares; although divergent accounts held the princess regent as a much larger twenty per cent shareholder for each of the "three Tonga registered companies" in petroleum mining (Open Corporates, 2013; Matangi Tonga, 2012; Field, 2011c; Sato, 2014).

In the space of five years, how many advisory committee meetings were conducted "from the Prime Minister's Office" with the "Chief Secretary and Secretary to Cabinet" as the "Chairman of the Committee?" (Prime Minister's Office, 2013). As the chair, it would be considered procedural for the prime minister's acting chief secretary 'Aholotu Palu to call regular meetings. Considering the advisory committee consisted of six members in which three were state officials exemplifying government interests, a fair question would have been to ask where the meeting minutes were archived.

Conspicuously, the people's representatives did not seem to know how to access minutes or request such information in the legislature. In the House, they stopped short of asking if parliament's standing committee on finance and public accounts "responsible for all matters pertaining to the collection of all public income" monitored licensing fees and mining royalties paid by Modulus Pacific Company Limited and its two subsidiaries to the Tongan state (Parliament of Tonga, 2013).

If it was indeed factual that the "three Tonga registered companies" would commence petroleum exploration in the present year of 2014, then what precisely were the terms of 
agreement on licensing fees and state royalties? (Matangi Tonga, 2012). The business risk was "the government coffer" might not have been collecting revenue worth its while from petroleum contracts publicised as celebratory, but in reality, shadowy and secretive (Sato, 2014, p. 19).

Significant points of argument raised by Sione Taione in the legislature on October 8th 2013 deserve attention here. Foremost, a petroleum mining license was issued by the reigning monarch in council, not altogether by the Minister Lord Ma'afu as the "sole competent authority for all exploration and mining of petroleum" of which the prime minister's office had detailed (Prime Minister's Office, 2013).

Additionally, Taione's unease about Modulus Pacific Company Limited's exclusive rights to explore for petroleum throughout " 5.5 per cent of the Tongan EEZ ... at 37,000 square kilometers of marine schedule lands" was not without cause. Under national law, newcomer prospecting companies were prohibited from entering the "area of land which [had] already been covered by [this] petroleum agreement" (Sato, 2014, p. 19-20; Tonga Petroleum Mining Act, 1988, p. 8).

Hypothetically Modulus Pacific Company Limited could, given its management satisfied the requirements of "an application for the extension" of a petroleum mining license, take out " 5.5 per cent of the Tongan EEZ" indefinitely (Tonga Petroleum Mining Act, 1988, p. 8; Sato, 2014, p. 20). Precisely the length of time in which this particular company would continue to mine a large designated area of the country's exclusive economic zone was left wide open to speculation.

His Majesty in Council may issue an exploration licence in respect of the whole or any part of the area of land applied for, and every exploration licence issued under this Act may, subject to the following provisos, authorise the licensee thereof to explore for petroleum 
over the whole or any part of the area of land specified in that license: Provided that an exploration license shall not be issued in respect of an area of land which has already been covered by a petroleum agreement ..." (Tonga Petroleum Mining Act, 1988, p. 8).

Every exploration licence shall be for an initial period of 2 years and thereafter may be extended from time to time upon an application for the extension thereof made and supported by evidence that the licensee had in fact carried out during the currency of the license exploration work upon a reasonable scale (Tonga Petroleum Mining Act, 1988, p. 8).

Lastly, nowhere in the Tonga Petroleum Mining Act (Revised Edition 1988) was liability for environmental damage explicitly specified. Truthfully, the legislation reflected the original date in which it was first instated as law, 1969. Tonga's petroleum act was out of time and out of line with the present day reality of climate change and environmental conservation. A discernible disparity became apparent. There was an absence of legal responsibility put on the state and petroleum companies to practice a duty of care towards the environment inside Tonga's exclusive economic zone. Starkly this contrasted against strict liability obligations under international law. In international waters, states and companies were required to conduct environmentally responsible seabed mineral exploration and exploitation.

Published in his 2014 article on Tonga's risky seabed mining ventures for the New Zealand International Review, Yoichiro Sato remarked that Modulus Pacific Company Limited was looking for an "international investment of US\$20-40 million" (Sato, 2014, p. 20). The amount Sato noted was business start-up capital for preliminary "exploration" said to 
commence this year. Not one public notice released by the advisory committee based in the Tongan Prime Minister's Office or from the company itself gestured to a start date.

The area amounts to 5.5 per cent of the Tongan $E E Z$, and international investment of US\$20-40 million is sought for the initial exploration, which will start in 2014. (Sato, 2014, p. 20).

Sato explained the problematic context couching petroleum exploration inside " 37,000 square kilometers" of Tonga's exclusive economic zone (Sato, 2014, p. 20). Put simply, “despite Tonga's 'democratic transition' after the Nuku'alofa riot of 2006, the royal family continues to dominate its politics" (Sato, 2014, p. 20). It was fair enough comment to suggest that Dr Kairat Sydykov's elusiveness would have been publicly honed in on and grilled if he were not affiliated to the princess regent Pilolevu as a business shareholder. How could an island Kingdom enact a discrete separation of power of traditional rulers from elected political leaders when citizens were not free to question, criticise, and overturn by majority consensus high-level decisions made behind closed doors to privilege a few and disenfranchise the masses?

Despite Tonga's 'democratic transition' after the Nuku'alofa riot of 2006, the royal family continues to dominate its politics. ...An investor group, comprising mysterious firms allegedly based in Denver and London and centred on a Russian individual, signed agreements with the Tongan government on hydrocarbons exploration and mining and established three Tonga-registered subsidiaries. Princess Royal Pilolevu Tuita owns 20 per cent shares in each of the three subsidiary firms, and the three firms were given 
exploration rights for eleven years and production rights for 35 years in the event of discovery of minerals in the '37,000 square kilometers of marine scheduled lands.' (Sato, 2014, pp. 19-20).

\section{Are the Minerva Reefs secured within Tonga's state sovereignty?}

Realistically, the Tongan public's interest in the continental shelf converged on whether the Minerva Reefs renamed Teleki Tokelau for north Minerva Reef and Teleki Tonga for south Minerva Reef were fixed within state borders (Cahoon, 2014). ${ }^{2}$ If the Tongan state's second partial submission on the outer limits of the continental shelf for a sea zone in the Lau-Colville Ridge was recognised, would this mean the Minerva Reefs were internationally recognised as belonging to Tonga? In short, yes it would be interpreted in such a way; although Fiji's dispute of the underwater reefs being counted as Tongan territory under the Convention on the Law of the Sea (1982) was an ongoing campaign which the Fijian government was determined to confront and overturn by a legal course of action.

There are various issues that need to be attended to. We have taken the legal line, the legal process regarding various other issues that have been raised at Minerva Reef as issued through government, a statement last week. We will follow the legal process as under the UNCLOS provision of the UN Convention on the Law of the Sea and that's in train. (Aiyaz SayedKhaiyum, Fiji interim attorney general cited in Rogers, 2011). 


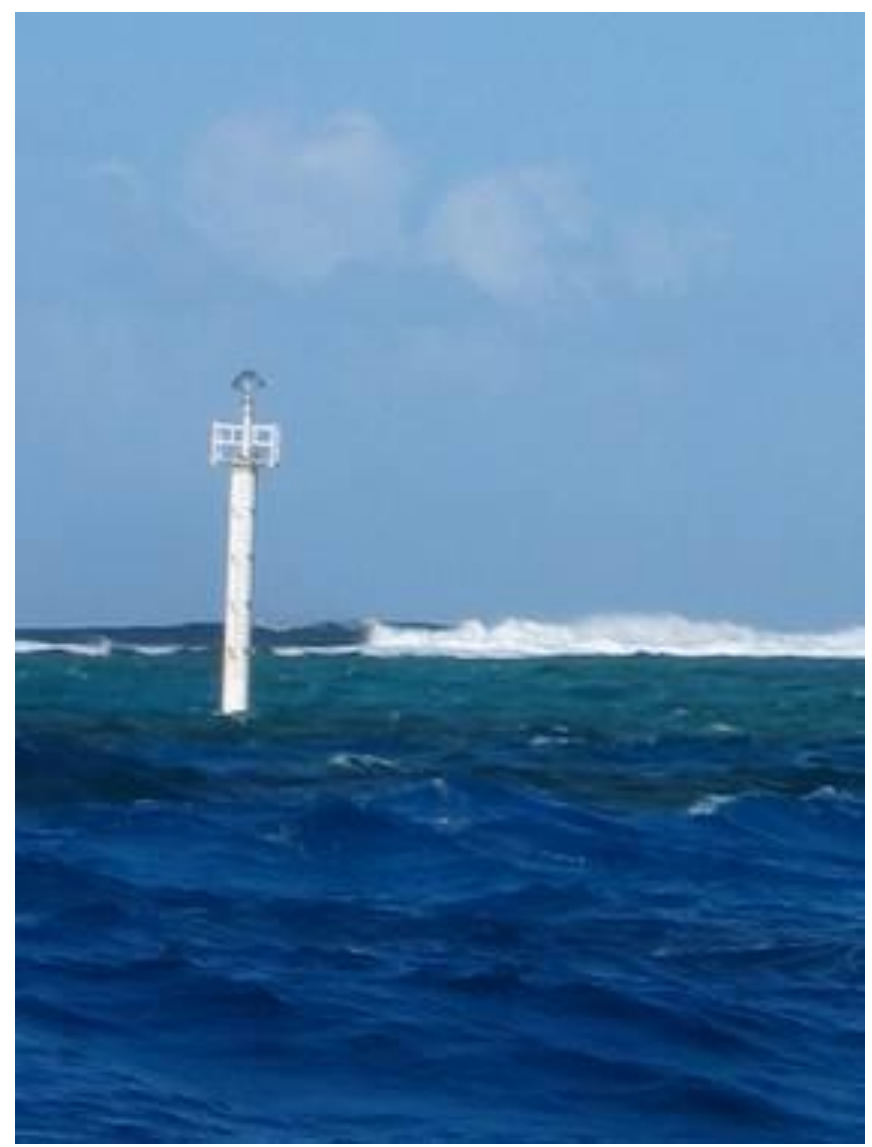

The beacon on Teleki Tonga, the south Minerva Reef, which is manned by His Majesty's Armed Forces for the Kingdom of Tonga. Photograph: Bob Belcher, 22 May 2008.

In fact, Fiji's legal construal of international law was that the Minerva Reefs "are inside Fiji's Exclusive Economic Zone" according to the United Nations Convention on the Law of the Sea (1982). Here were the western Pacific neighbours, Tonga and Fiji, with mutual histories of intermarriage, trade, 
resettlement, and cultural exchange. They had taken the same law and underwater reefs, giving them totally opposite meanings. Somewhere along the borderline they had stopped listening and communicating as neighbours, relatives, traders, and allies with more in common than in difference, and in a nutshell, it escalated the relationship trouble.

The second partial submission of 2014, in essence, fronted up to the United Nations Commission on the Limits of the Continental Shelf (CLCS) and to the Fijian government by stating explicitly that Tonga had sovereign ownership of Teleki Tokelau and Teleki Tonga. A plain-spoken strategy of spelling out national jurisdiction was elected for the reason that lengthening the outer limits of the continental shelf into the Lau-Colville Ridge was tied to measuring Tonga's geographic proximity to the sea area under claim.

Notably, Tonga recognised the underwater reefs as "the islands of Teleki Tonga and Teleki Tokelau" (Kingdom of Tonga, 2014, p. 3). In the partial submission text, islands was the operative word signalling the Minerva Reefs were by the state's estimation landed property as opposed to a maritime zone or space. Distinguishing and naming Teleki Tokelau and Teleki Tonga as islands not underwater coral ridges, crests, or mounds, had been adopted from King Taufa'ahau Tupou VI's 1972 royal proclamation that the Minerva Reefs fell within Tonga's dominion.

This was not without regional divergence. New Zealand foreign minister Murray McCully commented to public television news that south Minerva Reef was a "zone," revealing that to him this was a sea area: "The fact we've seen Navies getting into potential contact in the zone is pretty unhelpful frankly" (McCully cited in One News, 2011).

In 2014, the historical and cultural tradition of redefining two underwater reefs as islands and landmass of sovereign territory was uniquely continued. Tonga employed the legal 
term "historic title" to validate by international law that the 1972 royal proclamation had made the Minerva Reefs part of the state (Kingdom of Tonga, 2014, p. 2). Under this interpretation, the state had the title to the property Teleki Tokelau and Teleki Tonga, whereby title constituted the legal basis for the state's ownership of this particular property.

On 15 June 1972, a Royal Proclamation was published in the gazette of the Government of the Kingdom of Tonga asserting jurisdiction and control over the islands of Teleki Tonga and Teleki Tokelau: ... The islands of Teleki Tokelau and Teleki Tonga were recognized as part of the Tongan national territory by the South Pacific Forum of States in September 1972. (Kingdom of Tonga, 2014, pp. 2-3).

The Tongan government had concentrated on outspreading first into "the eastern part of the Kermadec Ridge" adjoining its south-eastern EEZ, and then into "the western part of the Lau [Colville] Ridge" flanking its south-western EEZ (Commission on the Limits of the Continental Shelf, 2010, pp. 12-13). But the wished-for enlargement was bound to cause friction and hold-ups in gaining assent as Lau-Colville collided with Fiji's 2009 partial submission, and Kermadec crashed into New Zealand's 2006 partial submission. Tonga was treading water beyond its national border contested by Fiji and New Zealand as theirs.

For Tongan nationals it was neither Lau-Colville or Kermadec but Teleki Tokelau and Teleki Tonga that stirred patriotism rooted in historical and emotional ties. Ordinary Tongans wanted an end to the June 2011 Minerva Reefs clash with the Fijian Navy from reoccurring or even worse, mounting into military action. Assurances from state leaders that the border encounter would not repeat itself had been minimal. In 
citizens' eyes, the Fijian neighbours had gotten unruly and needed to be told to stay in their own backyard and not come over looking to make trouble.

It was Samiu Vaipulu, Tonga's deputy prime minister who played straight into the hands of public anxiety and broke silence to the New Zealand media. Oddly, he was not the Prime Minister Lord Tu'ivakano who as the Minister for Foreign Affairs was expected far greater than his deputy to transmit a leadership message of conciliatory level-headed sense to the nation and region. Contrarily, Vaipulu confirmed a diplomat's worst nightmare "that if anyone interferes, action will be taken" (One News, 2011).

Referring to the Fijian Navy incident where "Tonga's navigational equipment" on the Minerva Reefs had been "dismantled," Vaipulu was not modest in saying that "they ran away" when sighting the arrival of the Tongan Navy (One News, 2011). Whether the Fijian Navy did flee as the deputy prime minister alleged was not the political point.

The fact was that in June of 2011 when the row erupted at sea, the heads of government were not in direct one-on-one communication, and nor were there designated senior ministers leading discreet and sensitive discussions on contested ownership of the Minerva Reefs. Indecisive leadership on Tonga's part meant the prospect of taking the diplomatic pathway had been botched. What did surface were nonessential players such as the deputy prime minister as well as a special advisor to the prime minister 'Ahongalu Fusimalohi, repeating hearsay to overseas media before diplomatic talks between governments had been established as the initial method for conflict resolution.

The Fijians recently went to the reef and dismantled Tonga's navigational equipment. In response, this week the Tongan government sent two of 
its own navy boats to protect their claim. "Our navy went back to their navy and they ran away [because] it's our territory," said [Tonga's deputy prime minister Samiu] Vaipulu. Tonga's Navy is still at the reef putting up navigational lights. The Tongan government [said] that if anyone interferes, action will be taken. "The fact we've seen Navies getting into potential contact in the zone is pretty unhelpful frankly," said [New Zealand] foreign minister Murray McCully. (One News, 2011).

As far as I'm concerned there was nothing. Well, maybe they [the Fijian and Tongan navies] may have met and waved at each other, but I would rather not speculate and infer that that was a confrontation or anything other than just probably meeting up at sea. ('Ahongalu Fusimalohi, special advisor to Tonga's prime minister cited in Rogers, 2011).

Quick off the mark, New Zealand media put out a spin on how the New Zealand government read political relations between Fiji and Tonga. "Fear" was the operative word (One News, 2011). According to public television news, New Zealand "feared" the competing claims on the Minerva Reefs would ignite conflict, in particular, military engagement.

The tit-for-tat battle is a situation New Zealand feared would happen. Both Fiji and Tonga claim Minerva Reef as their own. "They do not a have a right to those two islands, it belongs to his Majesty and the government of Tonga," said Samiu Vaipulu, Tonga's deputy Prime Minister. (One News, 2011).

Compounding this style of crisis reporting, New Zealand media had devised a cowboy-type theory about the cause of 
regional instability on the western Pacific frontier. Essentially it was believed that Tevita Mara's 2011 resettlement from Fiji to Tonga to evade sedition charges had upset the Bainimarama regime's apple cart, turning the neighbours on each other.

Fiji's military Prime Minister Frank Bainimarama is furious that one of his former military leaders, Lieutenant Colonel Tevita Mara, has now been allowed into Australia. The official Fijian government website refers to Tongan Navy boats at Minerva Reef, adding that New Zealand and Australia are rolling out the red carpet for Mara, who fled to Tonga last month after being charged with sedition in Fiji. The government website says Mara fled as a fugitive but was issued with a Tongan passport and both Australia and New Zealand appear willing to grant him a visa. (One News, 2011).

There was a time early on in the Tu'ivakano government's term when Tongan diplomacy could have offered a persuasive tactic for working out border disagreements vented by Fiji. Inside the senior cabinet clique Lord Ma'afu voiced his desire to pay a diplomatic visit to Suva, expressly to listen to and talk through Fijian government disapproval of Tonga's sovereign declaration over the Minerva Reefs. This was in February of 2011, five months before the June border tussle between the countries' respective navies.

Tonga's Prime Minister Lord Tu'ivakano who held the Foreign Affairs portfolio was open to Lord Ma'afu's suggestion for diplomatic talks with Fiji. He even considered travelling with him. Tonga understood the politically precarious situation of managing relations with the Bainimarama military regime as well as their kinship ties to Fiji better than the New 
Zealand government whose panic-stricken advice uttered by foreign minister Murray McCully was "for both sides to pause and reflect before upping the ante" (Field, 2011a).

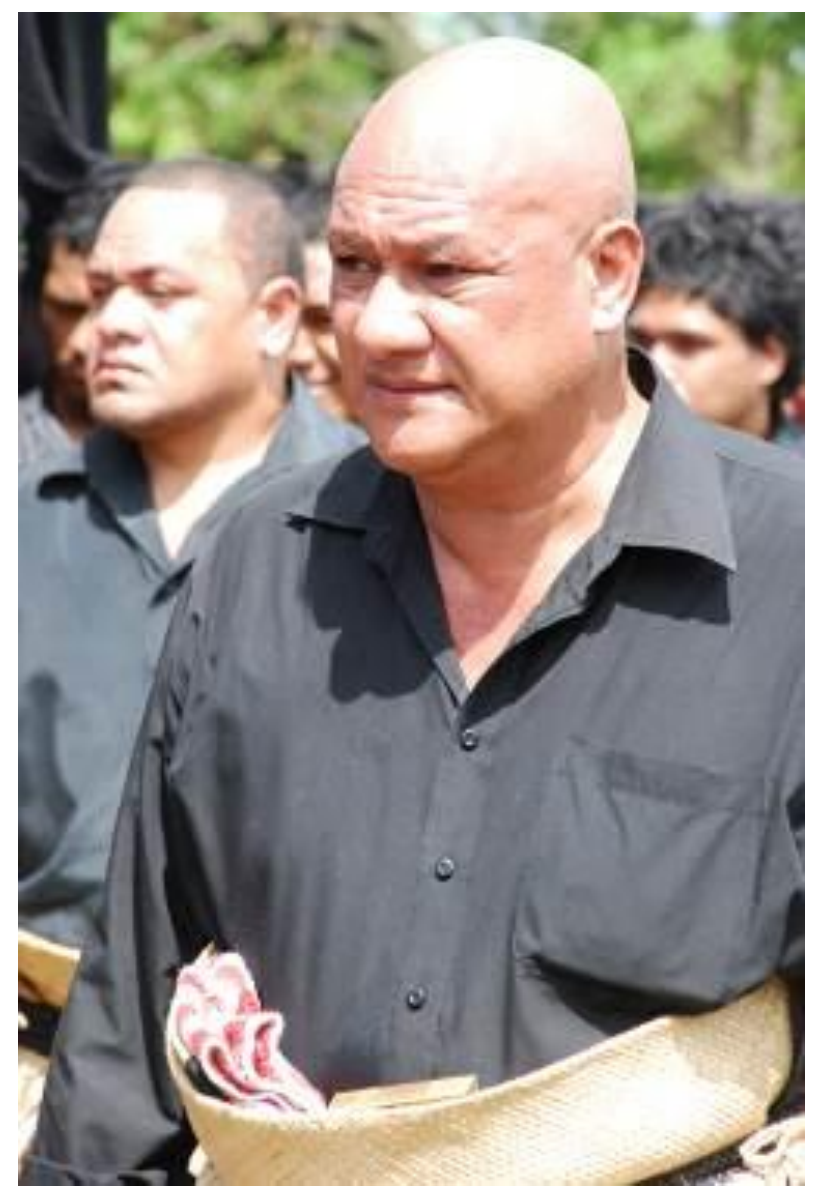

Lord Ma'afu at the late Lord Kalaniuvalu's funeral in the Kingdom of Tonga. Photograph: Melino Maka, April 2010. 
No prime minister or senior cabinet minister of significance to resolving the situation from the Fijian and Tongan governments was recklessly raising the stakes or gambling their country's security with a neighbour of whom they shared an interwoven history. To the contrary; at the beginning of 2011 Tonga was of the view that Ma'afu was an ideal negotiator in resolving matters with Fiji for two reasons that made relationship sense. He was a former Tongan military officer who knew Fijian officers in the military government and he was a noble groomed in Tongan diplomacy as a senior statesman; and not just any noble. The title Ma'afu resounded strongly with the 19th century Ma'afu who migrated from Tonga to Fiji's Lau islands to permanently settle, becoming known as the Tu'i Lau, the King of Lau.

Sila Balawa, Fiji's deputy permanent secretary for foreign affairs, spoke to Fijian media in March of 2011 affirming that Tonga's call for diplomacy and negotiation presented the way forward on the Minerva Reefs disagreement. Balawa made it known the countries were "open to dialogue" because "Tonga is very close to Fiji and we have links, we can sit with them and talk" (Gopal, 2011).

"As such, we maintain that it's always a part of Fiji but now we have a counter claim from Tonga for the reef," he said. "But we are open to dialogue with Tonga on the Minerva Reef issue. Since Tonga is very close to Fiji and we have links, we can sit with them and talk." Mr Balawa said Fiji would sit with Tonga as friends and talk in an attempt to find an amicable solution to the problem. "Talks are in progress for Fiji and Tonga to have bilateral talks on the reef issue and other issues," he said. "While no time frame has been set yet for the talks, it's our hope that talks will materialise in the near future." (Gopal, 2011). 
Contextualising Tonga's historical claim, on June 15th 1972 the late King Taufa'ahau Tupou IV issued a royal proclamation officially claiming the underwater reefs as "islands" of the Kingdom of Tonga's sovereign jurisdiction. Published in the English and Tongan languages by the Tonga Government Gazette Extraordinary, the writ was understood as a public declaration under national law and as being concordant with international decrees.

Tonga's maritime claims did have a longer history originating from the 19th century constitutional monarch King George Tupou I laying down an ocean dominion for his sovereign country. In many ways, it was Tupou I who set a precedent for how "historic title" over Tonga's maritime borders was inaugurated to which the 2014 partial submission on the outer limits of continental shelf traced the country's legal jurisdiction (Kingdom of Tonga, 2014, p. 14).

On August 24th 1887 the first monarch issued a royal proclamation in the Tonga Government Gazette that would "limit and define the extent and boundaries of Our Kingdom" (King George Tubou 1, 1887).

We do hereby erect as Our Kingdom of Tonga all islands, rocks, reefs, foreshore and waters lying between the fifteenth and twenty-third and a half degrees of south latitude and between the one hundred and seventy-third and the one hundred and seventyseventh degrees of west longitude from the Meridian of Greenwich. (King George Tupou I, 1887).

Moving forward to the 20th century royal proclamation of King Taufa'ahau Tupou IV in 1972, for forty-two years to the present-day His Majesty's Armed Forces had taken responsibility for manning the beacons on Teleki Tokelau and 
Teleki Tonga warning vessels of the underwater reefs, and for patrolling the Minerva Reefs and their twelve mile perimeter (King Taufa'ahau Tupou IV, 1972).

Whereas the Reefs known as North Minerva Reef and South Minerva Reef have long served as fishing grounds for the Tongan people and have long been regarded as belonging to the Kingdom of Tonga has now created on the Reefs islands known as Teleki Tokelau and Teleki Tonga; and whereas it is expedient that we should now confirm the rights of the Kingdom of Tonga to these islands; therefore we do hereby affirm and proclaim that the islands, rocks, reefs, foreshores and waters lying within a radius of twelve miles thereof are part of our Kingdom of Tonga. (King Taufa'ahau Tupou IV, 1972).

At the thirty-eighth year of Taufa'ahau the IV's royal proclamation in 2005, the Minerva Reefs flared up as a bone of territorial contention and contestation between the Kingdom of Tonga and the Republic of Fiji. Backing out on a former agreement, Fiji lodged a complaint with the International Seabed Authority stating it did not recognise Tonga's maritime claim that Teleki Tokelau and Teleki Tonga were under its state sovereignty.

The political inconsistency at work was highly questionable. At the 1972 South Pacific Forum in Suva, Fiji from the 12th to the 14th of September the member states, including the Republic of the Fiji Islands hosting the forum, agreed in principle to "Tonga's historical association with the Minerva Reefs" in "that there could be no question of recognising other claims to sovereignty over the reefs" (South Pacific Forum, 1972, p. 3). 
The "other claims" referred expressly to "the Ocean Life Research Association" founded by "[Las] Vegas real estate millionaire Michael Oliver" who desired to build a "libertarian society" free of "state intervention" on the underwater reefs (South Pacific Forum, 1972, p. 3; Newland, 2006). The counter claimant was not, at this time, Fiji.

Members of the Forum recognised Tonga's historical association with the Minerva Reefs, welcomed the Tongan Government's continuing interest in the area and agreed that there could be no question of recognising other claims, and specifically that of the Ocean Life Research Foundation, to sovereignty over the reefs. (South Pacific Forum, 1972, p. 3).

There were geopolitical drivers prompting Fiji's decision to break its word on the South Pacific Forum's 1972 agreement by renouncing in 2005 to the International Seabed Authority that the Minerva Reefs belonged to Tonga. It was speculated the Fijian government had reservations about Tonga's deep sea mining ambition to be a sponsoring state in international waters, namely the Lau-Colville Ridge.

If Tonga's possession of the Minerva Reefs as a maritime territory was left unchallenged then it looked promisingly positioned to make a continental shelf move into "the western part of the Lau [Colville] Ridge," acquiring this ocean domain for mineral exploration (Commission on the Limits of the Continental Shelf, 2010, pp. 12-13). Understandably Fiji desired this ocean terrain exclusively for its own seabed mining endeavours.

The 2009 partial submissions by the Republic of the Fiji Islands and the Kingdom of Tonga presented one month apart in April and May to the United Nations Commission on the Limits of the Continental Shelf (CLCS) were a warning sign. 
On paper these proposals might have looked to sidestep a Minerva Reefs embroilment on an international stage. But boiling under sea level border tensions had not subsided in country-to-country interactions.

The game changer in 2014 was that Tonga's second partial submission was set to reignite anxieties on Fiji and Tonga's rivalled claims that tried to step each other out. By extending the country's 200 mile exclusive economic zone 60 nautical miles into the Lau-Colville Ridge, Tonga had wilfully repositioned itself in a second border fracas with Fiji. Already quarrelling because Teleki Tokelau and Teleki Tonga had not been unequivocally resolved to Fijis satisfaction, the longer diplomatic communication was bungled the more it allowed political conditions to fertilise angst, tension, and unpredictable dogfights.

Tonga's two partial submissions on the outer limits of the continental shelf argued that "overlaps have not been resolved by means of maritime boundary delimitation agreements among the three States [Tonga, Fiji, and New Zealand] to this date (Kingdom of Tonga, 2009, p. 5; Kingdom of Tonga, 2014, p. 16).

These two parts of the Kermadec and Lau Ridges are regions over which there are overlaps of maritime spaces under the national jurisdictions of the Kingdom of Tonga, the Republic of the Fiji Islands, and New Zealand. These overlaps have not been resolved by means of maritime boundary delimitation agreements among the three States to this date. (Kingdom of Tonga, 2009, p. 5).

An acute observation initially penned in 2009, five years later in 2014 the same tune was being sung but this time, switched up a notch. Was Tonga any closer to preventing 
three countries - Tonga, Fiji, and New Zealand - from having outer continental shelf collisions? Had the Fiji and Tonga feud over two underwater reefs, which Tonga saw were their islands, been settled? Would Tonga attain an adequate law in 2014 protecting the ocean floor from deep sea mining damage and the state from liability?

Tendering a second partial submission to the United Nations maintaining the same position to that which was written in the first was telling. Twice "boundary delimitation" had not, by any means, settled continental shelf crossovers between states (Kingdom of Tonga, 2009, p. 5; Kingdom of Tonga, 2014, p. 16). The obstacle was evident but the way out blurry. Therefore, testing the legal practicability of charting a 60 nautical mile line from a country's baseline EEZ out to open sea, while knowing it would crash into a neighbouring country doing the identical exercise, was the whole point to proving "boundary delimitation" would not achieve the objective.

Which brought up a consequential query on boundary concessions between states: who decided the final delimitations to be made on marking out a state's continental shelf borderline in the situation of boundary conflicts? Being a state party to the United Nations Convention to the Law of the Sea (1982) since August 2nd 1995 meant Tonga had assented to the Commission on the Limits of the Continental Shelf (CLCS) as an authority on applying international law to how the state's outer limits would be defined and confined.

The Tongan government understood that international law did not give clear-cut answers to concluding discrepancies between states. What it had to confront was whether the United Nations system allowed the state to decide if the commission's recommendations on the second partial submission were an accurate application of the Law of the Sea (1982). Based on the 1972 royal proclamation over the 
Minerva Reefs, Tonga considered it had an unparalleled case and resultantly propelled this argument as the legal, historic, and cultural bargaining point. If its case was rejected, what possibilities for redress and challenging the decision-making process were there?

Noteworthy is the one-off consultation that did take place between states - Tonga, Fiji, and New Zealand - was part of the United Nations submissions procedure under article 76, annex II of the Convention on the Law of the Sea (1982) to the Commission on the Limits of the Continental Shelf (CLCS). Under the convention, a party state practiced a courtesy of asking another state on whose boundary they overlapped if they objected to their submission.

The standard convention was that the state being asked would not oppose, but instead, agree to the commission deliberating on the submission so as to appear an impartial objective party. Simultaneously they would make it known that the neighbour's continental shelf border intersected with their own claim. As the official communication exchange between states the purpose was to show the commission they had complied with international law and behaved "without prejudice" to one another's submissions on delimiting continental shelf boundaries.

Fiji and its eastern neighbour, the Kingdom of Tonga, have held consultations concerning Fiji's submission of information to the Commission. The Government of the Kingdom of Tonga has agreed not to object to the consideration by the Commission of this partial submission. This partial submission of information by Fiji to the Commission is without prejudice to delimitation of maritime boundary with the Kingdom of Tonga. (Republic of the Fiji Islands, 2009, p. 5). 
New Zealand notes that the area of extended continental shelf along the eastern Kermadec Ridge beyond 200 nautical miles contained in the Tongan submission overlaps in part with the area of extended continental shelf contained in the Northern Region of the New Zealand submission. (New Zealand Permanent Mission, 2009).

\section{An honest debate}

To turn an incisive jab towards my own kind - Pacific Islander academics, researchers, and writers - a dysfunctional aspect of the entire continental shelf business going off in our homeland states was the deficiency of opposition and debate. In theory, this should have been part-and-parcel of academia's social responsibility to bring to the public domain.

To our own detriment in the second decade of the $21 \mathrm{st}$ century, individuals and collectives affiliated to universities and research institutes who self-identify as Pacific Islanders have become spectators and onlookers of homeland state politics. By not saying anything, they have made themselves virtually redundant and out of the critic's job. Conventionally, the role of the critic continues to be overrun by Palangi (white/European) academics, along with a handful of Pacific Islander reporters and political commentators scurrying behind the knowledge authorities represented as scholarly book writers and intellectuals who are not their own people. I say this partly as a disappointed idealist who credits a somewhat old-school convention that intellectual freedom matters.

Often I am perplexed that my own identity group, Tongans, are quick to brag about the number of conferred doctorates they boast for a small population. If the truth be told, the 
highly educated stay silent, electing not to publish criticism of structural power disparities manoeuvred by traditional hierarchy and a top-heavy state resistant to further political reform. What is the point of gaining a doctoral degree, particularly in the human social sciences where most Tongans study, if one does not invest in this qualification to provoke critical thought and push boundaries of civil freedoms for greater social inclusion?

In the contemporary political climate where the research industry is commercially operated through government grants generating sought after revenue for the university coffers, business expediency gags criticism and independent thinking. Sovereignty and self-determination are therefore not principles exclusively measuring the confidence and safety of independent states. Academia, like media, experiences border security unrests. As the world becomes increasingly structured by global governance and corporate economics cementing single narratives of power, writing dissent and nonconformity is harder to sustain where many, as in the case of Tongan academics, are fearful to speak back to power.

It is difficult to find a homeland audience for unrestrained criticism, especially when Pacific Island states are indoctrinated to think and behave as the United Nations small island developing states; tiny, less important, and dependent on rich countries for their mere survival and right to exist as the poorer peoples of planet Earth in all ways imaginable. "What do they have left to imagine?" (Chatterjee, 1993, p. 5).

Partha Chatterjee in his 1993 book The Nation and its Fragments rationalised that the model scenario for developing states was co-authored by the United States and Europe for the unfortunate rest of the world. In the present-day, they continue to compose the dominant plot on how non-American and non-European others can emerge from colonial vestiges of empire into independent peripheral nations; always yielding to 
Western control of world affairs and grateful to be minor allies and aid recipients.

As a result, Chatterjee's line of reasoning constructed a counter narrative. In context, "even our imagination must remain forever colonized" (Chatterjee, 1993, p. 5). Self-will and self-determination vital to thinking outside "certain modular forms" of "nationalism," the state, and development have been thought out for the world's developing states to unthinkingly consume, digest, and excrete (Chatterjee, 1993, p. 5). Force-fed to countries delineated as the Third World, this dominant discourse presents itself as "history," fact, and the only truth available to them (Chatterjee, 1993, p. 5). And for that which we are about to receive, we are truly grateful; (a pun on an Americanised model verse for a Christian ritual of giving thanks before a meal, wholly intended).

History, it would seem, has decreed that we in the postcolonial world shall only be perpetual consumers of modernity. Europe and the Americas, the only true subjects of history, have thought out on our behalf not only the script of colonial enlightenment and exploitation, but also that of our anticolonial resistance and postcolonial misery. Even our imagination must remain forever colonized. (Chatterjee, 1994, p. 5).

American professor of history Stephen Cohen retrospectively viewed "the late 1970s and early 80s" as a golden age where dissent politics were publicly debated in mainstream media (Cohen, 2014). Tinged with nostalgia and sentimentality for an era he actively participated in as an American scholar of the political left, Cohen differentiated between the past and present conditions under which critics operate in public life. Back then, he mused, "we were always 
in a minority" but at least "we were present [and] we got our say" (Cohen, 2014).

I participated in the debates of the late 1970s and early 80s. They were called the debate between the detente-ists, those of us who wanted to reduce the cold war and the cold warriors who wanted to step up the cold war with the Soviet Union. But there was a real debate. We, the détente-ists were always in a minority, always in a minority; but we were present on the op-ed [opinion piece opposite the editorial] pages of the main American newspapers. This was before cable TV, but we were on television; we were on radio; we got our say. (Cohen, 2014).

To return to my dig at why public debate on Tonga's continental shelf politics and its association to deep sea mining had not shown up for the match, American foreign correspondent Chris Hedges made an insightful comment. Referring to how the United States Obama administration botched diplomatic relations with the Russian Federation over the Ukraine crisis as it currently unfolds, he exclaimed that "the last thing they're interested in [the American government] is an honest debate" (Hedges, 2014).

Well the last thing they're interested in is an honest debate. They have, they will pick and select, chose facts and even sometimes incidents that are not fact to perpetuate the narrative that they seek to disseminate. I mean, as a foreign correspondent my job was often [at] times to report on incidents and events that puncture that narrative, and that was true of every administration I covered. (Hedges, 2014). 
Here, I reflect on Hedges' notion that the government will deliberately hand "pick and select, chose facts and even sometimes incidents that are not fact to perpetuate the narrative that they seek to disseminate" (Hedges, 2014). In saying this, what is the Tongan state narrative on continental shelf politics, and how does it contradict the integration of climate adaptation into a national policy framework?

\section{The Tongan state narrative}

February 25th 2014 saw 'Aisake Eke, the Minister for Finance and National Planning at the Government of Tonga sign a grant agreement for $\$ 23.1$ million Tongan pa'anga with the Asian Development Bank's director general of the Pacific department, Xianbin Yao (Matangi Tonga, 2014). Tonga was one of nineteen developing states selected for the bank's Pilot Programme for Climate Resilience (PPCR). (Asian Development Bank, 2014a, 2014b).

The Ministry for Lands, Environment, Climate Change and Natural Resources who had pitched the proposal for funding was responsible for coordinating Tonga's climate resilience sector project across the state bureaucracy and vulnerable communities, and reporting to government and donors on progress and outcomes. This was the same ministry under Lord Ma'afu who also rolled out Tonga's deep sea mining enterprise as a state sponsor to Nautilus Minerals Incorporated. Detectably, there existed a policy disjuncture in that one ministry carried out resilience and exploitation concurrently under the pretext of environmental and natural resource sustainability.

Climate Investment Funds at the World Bank Group had set aside US $\$ 1.3$ billion dollars for the pilot programme, with money being distributed to country projects focused on strengthening resistance to climate change in state law, policy, 
infrastructure, budgets, as well as community activities (Climate Change Funds, 2014). There were five international banks financing Climate Investment Funds - African Development Bank, Asian Development Bank, European Bank, Inter-American Development Bank - with the World Bank Group manning the money from its Washington DC headquarters. Three participating countries from the Pacific Islands region, Papua New Guinea, Samoa, and Tonga competed for small slices of the US 1.3 billion dollar pie to stage their national climate strategies (Asian Development Bank, 2014a, 2014b; Climate Investment Funds, 2014).

Climate Investment Funds approved Tonga's grant "under phase II of the Pilot Programme for Climate Resilience (PPCR)" on December 9th 2013 (Asian Development Bank, 2014a). It took two months for the sign-off in Nuku'alofa and an "initial endowment of \$5 million" Tongan pa'anga "for the Tonga Climate Change Trust Fund" to be officiated (Matangi Tonga, 2014; Asian Development Bank, 2014b). Perceptibly, the Tongan state's novel scheme was to set-up a national trust that disbursed "small grants to help communities implement climate change adaptation and disaster risk resilience projects." It was thought to be "a first for the Pacific" Islands region (Matangi Tonga, 2014).

[The climate resilience sector project will] support an innovative sustainable financing mechanism that will provide small grants to help communities implement climate change adaptation and disaster risk resilience projects - a first for the Pacific in climate change adaptation and disaster risk reduction. An initial endowment of $\$ 5$ million will be provided to the Tonga Climate Change Trust Fund. (Matangi Tonga, 2014). 
Tonga had one major hitch to getting its climate resilience sector project off the ground in the most susceptible communities as well as embedded into state institutions. "There is no Cabinet endorsed government strategy for climate change adaptation formally in place yet in Tonga" (Climate Investment Funds, 2012, p. 5). And nor would there likely be ratification at the national executive in the near future; certainly not with the Tu'ivakano government.

Ranked highly by Tonga's cabinet was the drive for "increased offshore resources," namely deep sea minerals. "An extended continental shelf" would deliver seabed riches if the United Nations Commission on the Limits of the Continental Shelf (CLCS) gave a seal of approval to the two partial submissions pending decision (Government of Tonga, 2014). Obtaining a continental shelf rubber stamp under international law was fast proving to be easier said than done. But despite the legal complexity of getting tangled up in the neighbours' boundaries, the Tongan government was banking on "a positive ruling and acceptance of Tonga's submission" (Government of Tonga, 2014).

A positive ruling and acceptance of Tonga's submission on an extended continental shelf by the Commission will open up many opportunities for the Kingdom in terms of increased offshore resources, which can potentially contribute to Tonga's sustainable development and economic growth. (Government of Tonga, 2014).

And here lay the continental shelf conundrum. The "sustainable development" of deep sea minerals "and economic growth" cancelled out any credibility that climate resilience would be Tonga's overarching national priority (Government of Tonga, 2014). Put simply, the Government of Tonga was 
pushing two contradictory positions - economic growth by seabed mineral exploitation and resistance to climate change which effectively were irreconcilable state policies and approaches aimed at securing a sound future for the next generation.

In the end, the market won out. And why would it not be the stronghold of how poor countries imagine development into existence? It was Gilbert Rist who wrote "the market inevitably fans economic and military competition for access to (unevenly distributed) resources" (Rist, 1997, p. 187). The market, a term that can be used instead of the economy, relies on competition to thrive as the epitome of development; which is what Tonga and Fiji were doing over the Minerva Reefs and their continental shelf claims in the Lau-Colville Ridge. Stripped down to the naked truth, they were in "competition for access to (unevenly distributed) resources," deep sea minerals (Rist, 1997, p. 187).

\section{In social memory and meaning}

I would not write about the Kingdom of Tonga's affiliation to and affection for two coral reefs which lie largely underwater, revealing themselves modestly at low tide, if the story did not resonate in my own social memory and meaning. I have a dead uncle buried in 1962 on Teleki Tonga, the south Minerva Reef, along with three Tongan nationals. He was shipwrecked along with his father and fifteen Tongan men who were the crew and passengers aboard the Tuaikaepau. He died of dehydration the day before rescuers from the Royal New Zealand Air Force dropped supplies to the survivors.

His name was Fetaiaki Pulu and he was my father Seminati Pulu's first cousin. Their fathers were brothers, Soakai and Sioeli Pulu from Kolonga in the eastern district of Tongatapu, Tonga's main island. Soakai Pulu and four of his 
six sons, Fetaiaki, Toni, Sione, and Viliami are inscribed in oral history as the Kolonga boxing family, all having held national heavyweight titles. Soakai was Tonga's undefeated heavyweight national titleholder for nineteen years from 1934 to 1953.

He retired from boxing as the undefeated South Pacific heavyweight champion, most notably having beat a Fijian for the regional title by the name of Seminati. According to the Pulu family account, after the match Seminati asked Soakai to give his next son his Fijian first name to remember him by. My father, Soakai's nephew, was to whom he gave this Fijian boxer's name. Dad was born in October of 1947.

Seminati (my father) was the Pulu family's only national sprinter who won two bronze medals for Tonga in the 100 and 200 meters at the 1969 South Pacific Games held at Port Moresby in Papua New Guinea from the 14th to the 20th of August. He was twenty-one years old and tied second equal for both events with a New Hebrides sprinter Charles Godden. Awarded third place behind Godden, the gold medal went to a white French national Jean Bourne who represented French Polynesia.

In 1969 he paid his own airfare to the games and was not subsidised by the Government of Tonga for travel, starting blocks, and spikes (his sprint shoes). He was on a plumbing apprenticeship with the New Zealand Railways in Dunedin, and had been sent to the South Island in 1966 via a Tongan government trade training scholarship. A return airfare from Dunedin to Port Moresby was costly in the 1960s. The head plumber at the railways to whom he was apprenticed, an old Pakeha (white/European) man from Port Chalmers of Scottish descent, pitched in to financially assist. Dad has never forgotten him.

The state issued my father with a uniform and a registration number, not that he has ever complained or 
expected the Tongan government to pay his way. As an old fashioned Tongan who grew up before the aid and remittance psychology of hand-outs and monetary donations took hold of people's values, Seminati was satisfied with representing King and country. "That was enough for me," he has maintained for forty-five years. He is now sixty-six years old.

Compared to his heavyweight boxer cousins, Seminati was small in stature weighing in at 66 kilograms and 5 feet 8 inches in height. He sprinted because an individual sport in contrast to a team sport was the mentality he had been socialised with as a young boy training alongside his older cousin who boxed, Fetaiaki Pulu. Ritualistically they would run the Hahake beach road at 5 am in the morning before my father went to school. I believe dad was raised in a village environment to be independent, psychologically tough, physically athletic, and disciplined.

As a child, I thought this was indicative of all fathers from Tonga. As an adult, I learned this was not true but more, Seminati's personality type moulded by family-specific values and growing up bush; that is, being descended from a specific Tongan village juxtaposed (and discriminated against) as the archetypical country bumpkins who were considered the total opposite of town folk.

My dad has his own quirkiness and prejudices. He comments with disbelief, bordering disdain, about the current trend of obesity and non-communicable diseases rampant among Tongans. In all honesty, by his memory of the past Tongans were not overweight, physically inactive, and unhealthy. They were survivors, resourceful, hard-working, and self-willed like him; at least the men from the bush were according to his memoirs.

When Dad won the Tonga secondary schools athletics titles for the 100 and 200 meters in his senior year for 'Apifo'ou College in 1965, he set national youth records. He 
was officially recorded on file as Seni Pulu because Seminati or Semi for short was an unfamiliar sounding Fijian name. To this very day Tongans get my father's first name wrong, calling him Sam, Sammy, or Seni. It grates me that Tongan language speakers do not listen carefully and pronounce his Fijian first name correctly. And here I am, exposing my own quirkiness and prejudices; like father, like daughter.

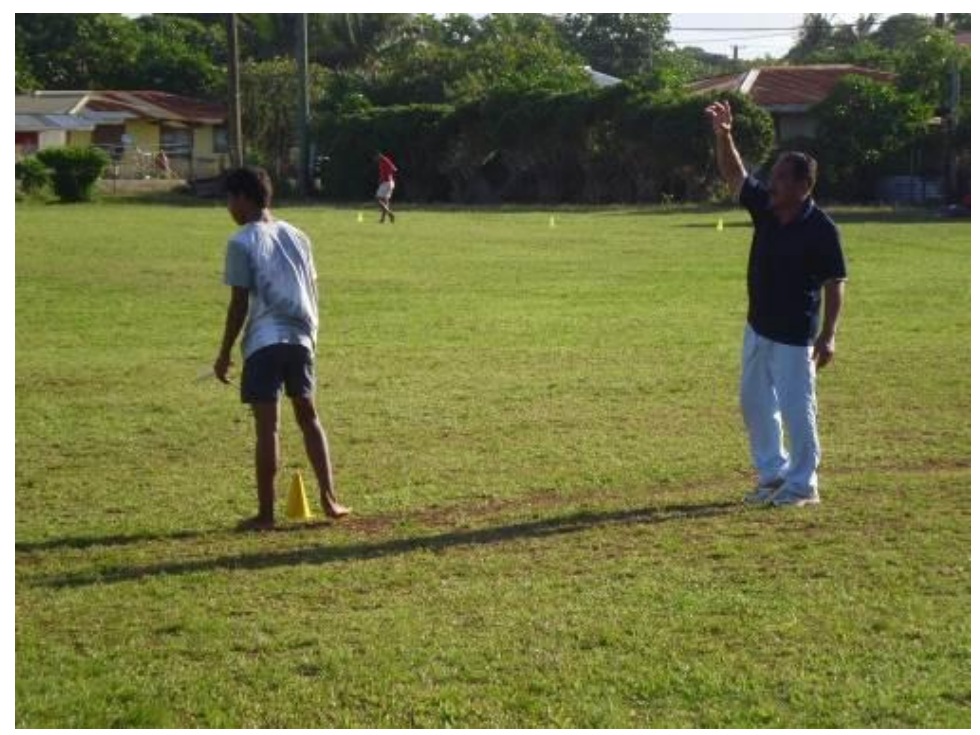

The author's father Seminati Pulu at sixty-six years old coaching students of Mo'unga 'Olive middle school in his Tongan village, Kolonga, competing at the secondary school athletics championships. Photograph: Teena Brown Pulu, 4 April 2014.

I do make a conscientious effort to correct them and explain he was named after a Fijian heavyweight boxer who fought his paternal uncle, Soakai Pulu. I behave like this because it is the family history of travels, events, and 
encounters I have inherited from paternity, from my Kolonga father, through social memory passed down in story across generations where most of our kinfolk now live in America, Australia, and New Zealand.

Kolonga families are transnational clans, the majority residing in diaspora and tracing ancestral ties to this origin village, a rural farming settlement where boxers, sprinters, and the odd academic are claimed and remembered as our people. Being vigilant and staunch about to whom I descend from and to where in the Pacific Ocean I trace my roots is the one method I possess as a daughter born in diaspora to honour my migrant father.

The contents of my life are a meaningful and purposeful reminder not to waste openings and breaks I have been afforded in New Zealand, my developed country of birth. In Tonga, my father was not given the same rights of access into the world, but rather, made chances to better himself happen out of sheer guts and an iron will that he and his descendants would secure a better future. We have that security in Auckland, my children and I. We are grateful not to have been born into a poor country, or worse still as Deepak Chopra observed, to be born into a poor family in a wealthy country such as New Zealand.

Poverty is a state of mind. Psychologically it can destroy the human spirit to do more than survive circumstances of birth, but live well, live every moment with reason, principle, and self-worth. Sadly I see this happen in Tonga today with dispossessed youth and women merely existing in a poor aiddependent society under the rule of men and their privileged women supporters who show no empathy towards how the other half live, and quite frankly, strut their complete and utter ignorance. When other people's lives of which you have no first-hand experience are not included in political 
consciousness one can quickly become emblematic of the oppressor, the tormenter, the intimidator.

I write this as a woman, a New Zealander who traces her ancestry to Tonga, and one who feels jaded by the language of international law and policy dominating Tonga's political pursuits. Seldom, if ever, have the policy directives of the Tu'ivakano government solved the country's quandaries, which are more often than not fast-money driven with little comprehension about the enduring consequences of taking shortcuts, doing knock-up jobs, and selling the seabed at a discount price. The state contradicts itself; asserting climate adaptation and resilience on the one hand, while aggressively exploiting the ocean for minerals, oil, and tuna.

It is one preoccupation for the Tongan state to sponsor mining companies in international waters, but it is another to collect sufficient royalties to mend a broke economy or for that matter, fix a wrecked environment. Just as it is one matter to carry out the legalities of acquiring a continental shelf, but it is another to exclude the very people who remember the true meaning of underwater reefs and to whom an enlarged oceanscape is intended to serve, in theory. Their stories are worth validating in a bureaucratic process that holds little relevance for citizens, and gains little buy-in from them if they are not included, informed, and involved.

Amidst the political fracture of wrestling the neighbour to hold on to underwater reefs that most Tongan nationals would never visit in their lifetime, there is one point of which I am quite sure of. If I sat down with any one of my friends who are Fijian nationals living in the homeland state or diaspora here in Auckland and told them my Tongan father's story of his first cousin who died on the south Minerva Reef, they would listen sympathetically. They would appreciate his emotional bond to a place in the ocean he had never been, but felt certain that it 
was part of his beloved country. And they would liken this human circumstance to their own.

The Government of Tonga should have listened and talked with care to the Fijian neighbours and relatives in February 2011 when Lord Ma'afu recommended a diplomatic visit to Suva. Back then, it was doable. Now, the opening had narrowed and almost four years on the Tu'ivakano government was at a close. As the Russian Federation foreign minister Sergey Lavrov described his one-on-one communication with the United States secretary of state John Carey over the present-day Ukraine crisis: "Personally we have very good chemistry, but we also understand that there are superiors, advisors, which sometimes doesn't help" (Lavrov, 2014).

Lavrov aptly illustrated the political conditions under which Ma'afu worked in the Tongan government case. He enjoyed cordial relationships with the Fijian government regime. At the same time he was answerable to his "superiors" and their "advisors, which sometimes doesn't help," frankly because they were not the right people to proficiently carry out diplomatic talks with a foreign country and close neighbour of whom your country stands in disagreement (Lavrov, 2014). For Tonga, another chapter written on how not to do diplomacy. A tactical approach to strengthening regional relationships was needed but it proved to be a skill driving a national vision which the current administration headed by the noble Lord Tu'ivakano fumbled, faltered, and flopped at.

Epeli Hau'ofa's starry-eyed allusion that an Oceania identity would one day unite Pacific Island states by a new form of regionalism shifting us away from Western colonial and economic domination has not happened (Hau'ofa, 2008, pp. 41-59). It is merely political lip-service manoeuvred by government leaders to publicise token policies on blue and green economies painting over the dismal misfortune of struggling against climate change in all the colours of the 
rainbow. But still, Pacific Islander academics quote and requote Hau'ofa's nostalgia that "the sea is our most powerful metaphor" bonding Oceania states and peoples as if they believe chanting sentimentality like their mantra will in fact get politicians to take what they publish seriously and put it into practice. This simply does not happen in the realpolitik of Pacific statehood.

I know this is true. I am an idealistic, well principled, leftwing anthropologist who over references Hau'ofa's writing because he was a Tongan born in diaspora who felt out-ofplace finding a fit in the homeland state (Hau'ofa, 2008, pp. 97-109). During his lifetime he remained an outsider at home. It equipped him with the social and intellectual liberty to speak back to power, unabashedly. I can relate. I write. I am a critic. Mainly because it is the one refined skill I have in my possession to pen my voice, have my say, and push my argument in public and up in your face, unapologetically.

But above that level of everyday experience, the sea is out pathway to each other and to everyone else, the sea is our endless saga, the sea is our most powerful metaphor, the ocean is in us. (Hau'ofa, 2008, p. 58). 


\section{References}

Ashton, C, (2013). Declaration by the High Representative, Catherine Ashton, on behalf of the European Union on the occasion of the International Day of the World's Indigenous Peoples: European Commission Memo. European Union, Brussels, Germany, August 9. Retrieved from

http:/ / europa.eu/rapid/press-release_MEMO-13-740_en.htm

Asian Development Bank. (2014a). 46351-002: Climate Resilience Sector Project: Project Data Sheet (PDS): Overview. Asian Development Bank, Manila, Philippines, April 23. Retrieved from http://www.adb.org/projects/46351-002/main

Asian Development Bank. (2014b). 46351-002: Climate Resilience Sector Project: Project Data Sheet (PDS): Details. Asian Development Bank, Manila, Philippines, April 23. Retrieved from http://www.adb.org/projects/46351-002/details

Brown Pulu, T. (2012). "Ma'afu's Word is in the Hills:" What is a Noble's Role in a Democratised Tonga? Te Kaharoa: The e-Journal on Indigenous Pacific Issues, 5 (1): 138-208.

Brown Pulu, T. (2013a). Deep Sea Tension: The Kingdom of Tonga and Deep Sea Minerals. Te Kaharoa: The e-Journal on Indigenous Pacific Issues, 6 (1): 50-76.

Brown Pulu, T. (2013b). Climate Change Blues: Sustaining Village Life in Tonga. Te Kaharoa: The e-Journal on Indigenous Pacific Issues, 6 (1): 260-305.

Cahoon, B. M. (2014). Tonga: Minerva. World Statesman Organization, Washington DC, United States of America, April 20. Retrieved from

http://www.worldstatesmen.org/Tonga.html

Chatterjee, P. (1993). The Nation and its Fragments: Colonial and Postcolonial Histories. Princeton, New Jersey, United States: Princeton University Press.

Climate Investment Funds. (2014). Pilot Programme for Climate Resilience. The World Bank Group (US), Washington DC, United States, April 30. Retrieved from

https://www.climateinvestmentfunds.org/cif/node/4

Climate Investment Funds. (2014). Strategic Programme for Climate Resilience for the Kingdom of Tonga. The World Bank Group (US), Washington DC, United States, April 13, Pp. 1-210. 
Cohen, S. (2014). Containment 2.0? Featuring Stephen Cohen and John Mearsheimer interviewed by Philip Lavelle. Cross-Talk, Russia Today, Moscow, Russian Federation, April 28. Retrieved from

https: / /www.youtube.com/watch?v=S9674pRBm6g\&feature=youtube gdata_player

Commission on the Limits of the Continental Shelf. (2010). United Nations Convention on the Law of the Sea Commission on the Limits of the Continental Shelf: CLCS/66, Twenty-Fifth Session, New York, United States of America, March 15 - April 23, Pp. 120.

Field, M. (2011a). Warships square off in Pacific feud. Stuff co $n z$, Auckland, New Zealand, June 16. Retrieved from

http://www.stuff.co.nz/national/5132572/Warships-square-off-inPacific-feud

Field, M. (2011b). Fiji, Tonga war over Minerva Reef. Stuff co nz, Auckland, New Zealand, May 16. Retrieved from

http://www.stuff.co.nz/world/south-pacific/5008060/Fiji-Tonga-warover-Minerva-Reef

Field, M. (2011c). New Scam in Tonga: This time Russian Oil Deal? Michael Field: Reporter and Author - Pacific, Auckland, New Zealand, February 13. Retrieved from

http://www.michaelfield.org/Tonga\%20oil.htm

Field, M. (2011d). Fiji claims part of Tonga as border dispute heats up. Michael Field: Reporter and Author - Pacific, Auckland, New Zealand, February 4. Retrieved from

http://www.michaelfield.org/reefs.htm

Field, M. (2010). Fiji confirms it wants part of Tonga. Michael Field: Reporter and Author Pacific, Auckland, New Zealand, February 8. Retrieved from

http://www.michaelfield.org/reefs.htm

Folau, L. (2013). Tonga to increase resilience to climate change. Matangi Tonga Online, Nuku'alofa, Tonga, May 15. Retrieved from

http://matangitonga.to/2013/05/15/tonga-increase-resilienceclimate-change

Fonua, P. (2013). MP alleges government corruption. Matangi Tonga Online, Nuku'alofa, Tonga, October 17. Retrieved from

http://matangitonga.to/2013/10/17/mp-alleges-governmentcorruption 
Gopal, A. (2011). Fiji, Tonga to settle Minerva Reef claim. The Fiji Times Online, Suva, Fiji, March 29. Retrieved from

http:/ / www.fijitimes.com/story.aspx?id=169436

Government of Tonga. (2014). Cabinet Sub-Committee on Maritime Boundary Delimitation Issues Including the Extended Continental Shelf (CSCMBDI-ECS). Ministry of Foreign Affairs and Trade, Government of Tonga, Nuku'alofa, Tonga, April 24. Retrieved from http://www.mic.gov.to/news-today/press-releases/4929-cabinet-subcommittee-on-maritime-boundary-delimitation-issues-includingthe-extended-continental-shelf-cscmbdi-ecs

Hau'ofa, E. (2008). We Are The Ocean: Selected Works. Honolulu, United States of America: University of Hawai'i Press.

Hedges, C. (2014). Last thing US wants in the world is democracy. It wants control. Chris Hedges interviewed by Sophie Shevardnadze. Russia Today, Moscow, Russian Federation, April 28. Retrieved from

https:/ / www.youtube.com/watch?v=OZnKKMFL6no\&feature=youtube _gdata_player

Hill, B. (2014). Pro China policies may alienate overseas Pacific communities. Radio Australia: Pacific Beat, Australian Broadcasting Corporation, Melbourne, Australia, January 23. Retrieved from

http://www.radioaustralia.net.au/international/radio/program/pacifi c-beat/pro-china-policies-may-alienate-overseas-pacificcommunities/1253018

International Seabed Authority. (2014). Contractors. International Seabed Authority, Kingston, Jamaica, April 19. Retrieved from

http://www.isa.org.jm/en/scientific/exploration/contractors

International Seabed Authority, (2012). Tonga Becomes Second Developing State to Sign Contract with ISA. International Seabed Authority, Kingston, Jamaica, January 12. Retrieved from

http://www.isa.org.jm/en/node/714

International Seabed Authority. (2008a). Press Release, 30 May, SB/14/8. International Seabed Authority Council (AM) [Annual Meeting], Fourteenth Session, Kingston, Jamaica, 26 May - 6 June.

International Seabed Authority. (2008b). Nauru Ocean Resources Incorporated: Application for Approval of a Plan of Work for Exploration, 21 April 2008, ISBA/14/LTC/L.2. International Seabed Authority Legal and Technical Commission, Fourteenth Session, Kingston, Jamaica, 26 May - 6 June. 
King George Tupou I. (1887). Royal Proclamation. Tonga Government Gazette, Nuku'alofa, Tonga, August 24, Volume II, Number 55.

King Taufa'ahau Tupou IV. (1972). Proclamation. Tonga Government Gazette Extraordinary, Nuku'alofa, Tonga, June 15, Number 7.

Kingdom of Tonga. (2009). Executive Summary: A Partial Submission on the Outer Limits of the Continental Shelf of the Kingdom of Tonga Pursuant to Part VI of and Annex II to the United Nations Convention on the Law of the Sea. Submission to the Commission on the Limits of the Continental Shelf through the SecretaryGeneral of the United Nations, May 2009. Ministry of Foreign Affairs, Ministry of Justice, Ministry of Lands, Survey, Natural Resources and Environment, and Tonga Defence Services at the Government of Tonga, Nuku'alofa, Kingdom of Tonga, Pp. 1-22.

Kingdom of Tonga. (2014). Executive Summary: A Partial Submission on the Outer Limits of the Continental Shelf of the Kingdom of Tonga in the Western Part of the Lau Colville Ridge Pursuant to Part VI and Annex II to the United Nations Convention on the Law of the Sea, Part I: Submission to the Commission on the Limits of the Continental Shelf through the Secretary-General of the United Nations, April 2014. Attorney General's Office, His Majesty's Armed Forces, Ministry of Foreign Affairs and Trade, Ministry of Lands, Environment, Climate Change and Natural Resources at the Government of Tonga, Nuku'alofa, Kingdom of Tonga, Pp. 139.

Lavrov, S. (2014). Russian Federation Foreign Minister Sergey Lavrov Interviewed by Russia Today. Russia Today, Moscow, Russian Federation, April 23. Retrieved from

https: / / www.youtube.com/watch?v=m3FihkBjbms

Matangi Tonga. (2014). ADB grants $\$ 23.1$ million for Tonga climate resilience. Matangi Tonga Online, Nuku'alofa, Tonga, February 26. Retrieved from

http://matangitonga.to/2014/02/26/adb-grants-231-million-tongaclimate-resilience

Matangi Tonga. (2013a). Tonga Trench surveyed by Japan. Matangi Tonga Online, Nuku'alofa, Tonga, October 22. Retrieved from

http://matangitonga.to/2013/10/22/tonga-trench-surveyed-japan

Matangi Tonga. (2013b). Tonga Seabed Minerals Bill to go to parliament this year. Matangi Tonga Online, Nuku'alofa, Tonga, March 15. Retrieved from

http://matangitonga.to/2013/03/15/tonga-seabed-minerals-bill-goparliament-year 
Matangi Tonga. (2012). US group celebrates new oil exploration agreements with Tonga. Matangi Tonga Online, Nuku'alofa, Tonga, February 22. Note: The article is incorrectly dated on Matangi Tonga Online. It should read 31 January 2011. Retrieved from

http://matangitonga.to/2012/02/22/us-group-celebrates-new-oilexploration-agreements-tonga

Ministry of Information and Communications. (2011). News Today: US Oil Exploration agreements with Tonga to start drill in 2014. Tonga Government Portal, Ministry of Information and Communications, Nuku'alofa, Tonga, February 7. Retrieved from

http://mic.gov.to/community-based/2139-us-oil-explorationagreements-with-tonga-to-start-drill-in-2014

Newland, A. (2006). A true record of the Minerva Reef saga of 1972 and the part played by a Tongan Shipping Company Vessel Olovaha. Queen of the Isles, Stevenage, United Kingdom, December. Retrieved from

http://www.queenoftheisles.com/HTML/Republic\%20of\%20Minerva.h $\underline{\mathrm{tml}}$

New Zealand Permanent Mission. (2009). New Zealand Permanent Mission to the United Nations Letter to the Secretary-General of the United Nations: UN/7/121A. New Zealand Permanent Mission to the United Nations, New York, United States of America, 29 June.

One News. (2011). Showdown between Tonga and Fiji looms. One News, Television New Zealand, Auckland, June 11. Retrieved from http://tvnz.co.nz/world-news/showdown-between-tonga-and-fijilooms-4221560

Open Corporates. (2013). Modulus Pacific Co. Limited. Open Corporates, United Kingdom, October 5. Retrieved from

https://opencorporates.com/companies/to/9001356

Parliament of Tonga. (2013). Standing Committee on Finance and Public Accounts. Parliament of Tonga, Nuku'alofa, Tonga, October 1. Retrieved from

http://www.parliament.gov.to/index.php/parliamentarybusiness/committees/standing-committees/standing-committeeon-finance-and-public-accounts

Paskal, C. and Lodge, M. (2009). A Fair Deal on Seabed Wealth: The Promise and Pitfalls of Article 82 on the Outer Continental Shelf. Chatham House Briefing Paper, Energy, Environment and Development Programme, February, EEDP BP 09/01, Pp. 1-8. 
Persand, S. (2005). A Practical Overview of Article 76 of the United Nations Convention on the Law of the Sea. Mauritius Oceanography Institute United Nations and the Nippon Foundation of Japan, Pp. 1-37.

Prescott, V. and Boyes, G. (2000). Undelimited Maritime Boundaries in the Pacific Ocean Excluding the Pacific Region. Maritime Briefing, 2 (8): $1-50$.

Prime Minister's Office. (2013). Allegations towards Government corruption on Modulus Pacific unfounded. Prime Minister's Office, Government of Tonga, Nuku'alofa, Tonga, November 20. Retrieved from

http:/ / www.mic.gov.to/news-today/press-releases /4691-allegationstowards-government-corruption-on-modulus-pacific-unfounded

Rist, G. (1997). The History of Development: From Western Origins to Global Faith. New York, United States: Zed Books Limited.

Rogers, J. (2011). Fiji and Tonga play down Minerva Reef spat. Radio Australia: Pacific Beat: Australian Broadcasting Corporation, Melbourne, Australia, June 15. Retrieved from

http://www.radioaustralia.net.au/international/radio/onairhighlights /fiji-and-tonga-play-down-minerva-reef-spat

Rowling, M. (2014). Has climate adaptation lost its way? Thomsen Reuters Foundation, New York, United States of America, April 7. Retrieved from

http://www.trust.org/item/20140407082859-tus25/?source=shtw

Sato, Y. (2014). Tonga's risky seabed mining ventures. New Zealand International Review, 39 (2): 19-20.

Schofield, C. (2010). The Delimitation of Maritime Boundaries of the Pacific Island States. Paper Presented at the International Seminar on Islands and Oceans 2010, Alaska, Tokyo, January 20$\underline{22 .}$

Seabed Disputes Chamber. (2011). Responsibilities and Obligations of States Sponsoring Persons and Entities With Respect to Activities in the Area: Advisory Opinion. Seabed Disputes Chamber of the International Tribunal for the Law of the Sea, Hamburg, Germany, February 1, Pp. 1-76.

Tonga Petroleum Mining Act. (1988). Tonga Petroleum Mining Act (Revised Edition 1988). Commencement [30 January 1970], Kingdom of Tonga, Pp. 1-13. 
United Nations. (2014). Receipt of the submission made by the Kingdom of Tonga to the Commission on the Limits of the Continental Shelf. The Secretary-General of the United Nations, Reference: CLCS.73.2014.LOS (Continental Shelf Notification), United Nations Headquarters, New York, United States, April 24.

United Nations. (2009). Receipt of the submission made by the Kingdom of Tonga to the Commission on the Limits of the Continental Shelf. The Secretary-General of the United Nations, Reference: CLCS.46.2009.LOS (Continental Shelf Notification), United Nations Headquarters, New York, United States, May 14.

United Nations. (2007a). 61/295: United Nations Declaration on the Rights of Indigenous People. Resolution Adopted by the General Assembly, 61st Session, 107th Plenary Meeting, New York, United States of America, September 13, Pp. 1-18.

United Nations. (2007b). Declaration on the Rights of Indigenous People. United Nations Permanent Forum on Indigenous Issues, New York, United States of America, September 13. Retrieved from http://undesadspd.org/IndigenousPeoples/DeclarationontheRightsofI ndigenousPeoples.aspx

United Nations. (1982). United Nations Convention on the Law of the Sea (UNCLOS). Montego Bay, Jamaica, December 10, Pp. 1-208.

United States Energy Information. (2013). Kazakhstan. United States Energy Information Administration, United States Department of Energy, Washington DC, United States of America, October 28. Retrieved from

http://www.eia.gov/countries/country-data.cfm?fips $=\mathrm{kz}$

\section{Photographs}

Photograph by Government of Tonga, 23 April 2014: Miguel de Serpa Soares, Lord Ma'afu.

Photograph by Matangi Tonga Online, 22 February 2012: Kairat Sydykov, Christine Utu'atu, 'Aminiasi Kefu, Natalia Lapina, Lord Ma'afu.

Photograph by Matangi Tonga Online, 22 February 2012: Joey Mataele, Natalia Lapina.

Photograph by Bob Belcher on 22 May 2008 and reposted by Michael Field on the website, Michael Field: Reporter and Author-Pacific in 2010: Beacon located on Teleki Tonga, south Minerva Reef, manned by His Majesty's Armed Services of the Kingdom of Tonga.

Photograph by Melino Maka, 2010: Lord Ma'afu.

Photograph by Teena Brown Pulu, 4 April 2014: Seminati Pulu. 


\section{Endnotes}

1 Who's who in the zoo is used here as a tongue-in-cheek reference. Tonga's who's who in the zoo points to the ruling elite; namely the royal family, the nobility, and the business elite. The friendliness of certain business people with the traditional upper class is politically motivated. Gaining a favourable economic position in the social hierarchy to exploit working class and underclass Tongans for profit is a driver of the middle class business sector. Tonga is, by all and sundry, a society structured by capitalist values where money, assets, and showing off wealth is revered as demonstrating a person's material power and social status.

Who's who in the zoo is the Master of Philosophy thesis title of Richard Pamatatau, who descends from Mauke in the Cook Islands and is currently a journalism lecturer at Auckland University of Technology.

2 The timeline on the Minerva Reefs' political status cited below illustrates the ongoing tension between Fiji and Tonga as to whether the territory falls within their respective sovereign jurisdictions.

See Cahoon, B. M. (2014). Tonga: Minerva. World Statesman Organization, Washington DC, United States of America, April 20. Retrieved from

http://www.worldstatesmen.org/Tonga.html

I have amended Cahoon's original script on the modern history of the Minerva Reefs for factual correctness and added in significant events and detail that were not recorded.

9 September 1829

An Australian whaling ship Minerva wrecks on the south reef.

1854 British Captain H. Denham of the HMS Herald chartered the two reefs, north and south, naming them the Minerva Reefs.

1942 - $1945 \quad$ United States of America military forces occupied the underwater atolls during the Pacific Campaign of World War II.

6 July 1962 A Tongan twenty ton cutter measuring 51 feet in length called the Tuaikaepeau was shipwrecked on the Minerva Reefs with seven crew and ten passengers. Four of the seventeen Tongans died on the south Minerva Reef before being rescued, Sione Lousi, Sione Sikimeti, Fatai Efiafi and Fetaiaki Pulu, and one drowned, Sateki Fifita. In total, there were twelve survivors. 
24 November 1966

The Minerva Reefs were annexed by Captain Tevita Fifita on behalf of the Kingdom of Tonga. Tevita Fifita captained the Tuaikaepeau that was shipwrecked on the south Minerva Reef in 1962 and lost his son who was drowned, Sateki Fifita.

1971 The Minerva Reefs were colonised by the Phoenix Foundation, a group of libertarians based in the United States of America.

19 January 1972 The Republic of Minerva declaration made by the Phoenix Foundation is not legally or territorially recognised.

24 February 1972 The Kingdom of Tonga restates its claim at the South Pacific Forum held in Suva, Fiji, from 12 - 14 September under the premiership of King Tafau'ahau Tupou IV.

15 June 1972 The Minerva Reefs are formally defined as part of the Kingdom of Tonga by the royal proclamation of King Taufa'ahau Tupou IV which is recognised by the Republic of Fiji. In addition, Fiji had gained sovereign independence as a British colony in 1970 .

21 June 1972 The Minerva Reefs are occupied by the Kingdom of Tonga and named Teleki Tokelau for the north Minerva Reef, and Teleki Tonga for the south Minerva Reef.

1982 For three weeks a group led by Morris C. Davis attempts to re-occupy the Minerva Reefs but is forced off by the Tongan military.

November 2005 The Republic of Fiji lodges a complaint with the International Seabed Authority concerning their territorial claim over the Minerva Reefs and issue a statement not recognising maritime water claims over the disputed area by Tonga. 